\title{
13. MAJOR AND MINOR ELEMENTS IN HYDROTHERMAL AND PELAGIC SEDIMENTS OF THE GALAPAGOS MOUNDS AREA, LEG 70, DEEP SEA DRILLING PROJECT ${ }^{1}$
}

\author{
A. A. Migdisov, B. P. Gradusov, N. V. Bredanova, E. V. Bezrogova, B. V. Saveliev, and O. N. Smirnova, Institute of \\ Geochemistry and Analytical Chemistry, USSR Academy of Sciences, Moscow 117334, USSR
}

\section{INTRODUCTION}

Interaction between young basaltic crust and seawater near the oceanic speading centers is one of the important processes affecting the chemical composition of the oceanic layer. The formation of metalliferous hydrothermal sediments results from this interaction.

The importance of the interaction between seawater and basalt in determining the chemical composition of pore waters from sediments is well known. The influence of mineral solutions derived from this interaction on ocean water composition and the significant flux of some elements (e.g., Mn) are reported by Lyle (1976), Bogdanov et al. (1979), and others. Metal-rich sediments found in active zones of the ocean basins illustrate the influence of seawater-basalt interaction and its effect on the sedimentary cover in such areas. The role of hydrothermal activity and seawater circulation in basalts with regard to global geochemistry cycles has recently been demonstrated by Edmond, Measures, McDuff, McDuff et al. (1979), and Edmond, Measures, Mangum (1979).

In the area of the Galapagos Spreading Center the interaction of sediments and solutions derived from interaction of seawater and basalt has resulted in the formation of hydrothermal mounds. The mounds are composed of manganese crusts and green clay interbedded and mixed with pelagic nannofossil ooze. These mounds are observed only in areas characterized by high heat flow (Honnorez, et al., 1981) and high hydrothermal activity.

Hydrothermal mounds were studied by deep-tow (Sclater and Klitgord, 1973; Lonsdale, 1977), by the submersible Alvin (Corliss et al., 1979), and by direct drilling during Leg 54 (Hekinian et al., 1978; Natland et al., 1979; Rosendahl, Hekinian et al., 1980) of the Deep Sea Drilling Project (DSDP). Green clay and Mn-crust sampled from Galapagos mounds are very similar to those observed in the FAMOUS area (Hoffert et al., 1978, 1980).

The first analytical data on samples obtained from these expeditions show a significant difference between green clays and Mn crusts from the Galapagos hydrothermal mounds and metalliferous sediments recovered from the mid-oceanic ridges, especially the East Pacific Rise (Boström and Peterson, 1969; Bender et al., 1971;

\footnotetext{
${ }^{1}$ Honnorez, J., Von Herzen, R. P., et al., Init. Repts. DSDP, 70: Washington (U.S. Govt. Printing Office).
}

Sayles and Bishoff, 1973; Bonatti, 1975; Cronan, 1976, Migdisov, Girin et al., 1979).

The metalliferous sediments from mid-oceanic ridges directly cover basaltic basement; they consist of $\mathrm{Fe}$ and $\mathrm{Mn}$ hydroxides and $\mathrm{Fe}$ smectites and are enriched by many minor and trace elements $(\mathrm{Ba}, \mathrm{Ni}, \mathrm{Cu}, \mathrm{Zn}, \mathrm{Cd}$, $\mathrm{Sb}, \mathrm{Mo}, \mathrm{REE}$, etc.). Th, $\mathrm{Ce}, \mathrm{Rb}, \mathrm{Cr}$, and some other elements were depleted in these sediments relative to the deep oceanic clays. In contrast, hydrothermal sediments from the Galapagos mounds are poor in all these elements (Hekinian et al., 1978; Hoffert et al., 1980) and are both vertically and laterally restricted (Honnorez et al., 1981).

Various hypotheses on the origin of the hydrothermal mounds sediments were proposed by Hoffert et al. (1980) and Dymond et al. (1980). They are as follows:

1) Deposition from solution, resulting in wide-spreading sedimentary layers.

2) Interaction of pelagic oozes in the mounds area sedimentary cover with upward percolating hydrothermal solutions which replace the pelagic ooze by green clays.

3) Upward flux of hydrothermal solutions from locally permeable zones of basement through the sedimentary cover, with the formation of minerals resulting from an advancing oxidation gradient, without any interaction of solutions with pelagic sediments.

On Leg 70 of the Deep Sea Drilling Project (DSDP), a more detailed series of holes was drilled in 30 to 40 meters of sedimentary cover, both on mounds and in an off-mounds area. Regions of low heat flow without mound occurrences were also investigated. The hydraulic piston corer (HPC) was used, and detailed sampling of undisturbed sedimentary sections was accomplished.

Data obtained on Leg 70 (Honnorez et al., 1981) suggest that the hydrothermal sediments are local in regional extent, which allows us to exclude the first hypothesis. Some aspects of the third hypothesis also are questionable given the data obtained from Leg 70. For example, differences in thickness of pelagic ooze from mounds, off-mounds, and low heat-flow area sedimentary sections were observed. The evidence of microfossil tests, replacement, and infilling by smectite (Honnorez et al., 1981; Schrader et al., 1980) also casts doubt on the third hypothesis. However, data on the element distribution in sediments indicate that the hypothesis offered by Dymond et al. (1980) may be correct-namely, element differentiation through a redox-potential gradient in sedimentary sections. The data of Schrader et 
al. (1980) maybe taken to suggest that in the mounds smectite textures have been produced both by replacement of pelagic sediments and by open space filling. The authors recognized "complete replacement of Foraminifera tests"' in all mounds holes of Leg 54. They noted that this type of texture is not common statistically and is "often obscured by overgrowth of additional green clay.' Open space filling textures have been observed as "'zoned and sequential infillings of void spaces," implying "controlled deposition." The authors suggested that either types of smectite formation are concurrent or the process of replacement may be assumed to be slightly later. At the same time the relative role of both processes in smectite generation in mounds is not yet clear, and geochemical data supporting void infilling processes are absent.

The problem of the redistribution of major elements in the pelagic ooze during their dissolution and replacement has also not been resolved.

In light of these problems, the purpose of this chapter is the following:

1) To study changes with depth in the mineralogical and chemical composition of sediments in mounds cores.

2) To compare and correlate changes in the distribution of major and minor elements on mounds, offmounds, and in low heat-flow areas.

3) To speculate on the origin of hydrothermal sediments on the basis of obtained data.

\section{METHODS OF ANALYSES}

Prepared samples were washed to remove marine salts before analysis. Different techniques were used for determination of major and minor elements.

Data on major elements were obtained both by X-ray fluorescence (XRF) and chemical techniques. Samples were heated to $105^{\circ} \mathrm{C}$ prior to analysis. The chemical technique used, including determination of volatile components $\left(\mathrm{H}_{2} \mathrm{O}^{+}, \mathrm{CO}_{2}\right)$ and the oxidation state of $\mathrm{Fe}$, is discussed by Migdisov, Girin et al. (1979).

XRF analyses were performed on a 28 -channel PW-1600 "Philips" machine. A description of the procedure is given in Tsameryan et al. (1980).

Data on the major elements, determined by two independent techniques, were very similar and are presented in Tables 1-6. Numbers represent the mean value of the two analyses.

Minor and trace elements were determined by XRF, atomic absorption, and instrumental neutron activation. $\mathrm{Cr}$ and $\mathrm{V}$ were analyzed by XRF during major element determination. $\mathrm{Li}, \mathrm{Rb}, \mathrm{Sr}, \mathrm{Ni}$, $\mathrm{Zn}, \mathrm{Cu}$, and $\mathrm{Pb}$ were analyzed by the atomic absorption method using Perkin Elmer-405 and Perkin Elmer-603 machines. For Pb determination, a graphitic cuvette HGA-76 B machine was used in some cases (Sedyh et al., 1980). Neutron activation analyses were carried out using the technique described by Migdisov et al. (1980). A $40-\mathrm{cm}^{3} \mathrm{Ge}(\mathrm{Li})$ detector and Nokia LP 4900 channel analyzer were used. In some cases radiochemical concentrations of rare earth elements (REE) were examined.

Mineralogical and structural anomalies of the hydrothermal clay minerals were also studied. Measurements were made on a diffractometer DRON-2, with $\mathrm{Fe}$-radiation filtered with $\mathrm{Ni}$ using a common sample treatment technique.

\section{MAJOR ELEMENTS}

The data obtained are shown in Tables 1-10 and Figures 1-17. Figure 1 presents the distribution of some elements with depth at two mounds sites, 507 and 509. An inverse relationship in $\mathrm{Fe}$ and $\mathrm{Mn}$ concentrations exists within the hydrothermal sediments. The iron-rich smec- tites lack Mn, which is concentrated in the uppermost layer of the mound in the form of Mn crusts. In turn, very little $\mathrm{Fe}$ is found in the manganese crusts.

There are some cases where full fractionation of $\mathrm{Fe}$ and $\mathrm{Mn}$ is not observed. These are: (1) in oxidized smectites which are localized directly underneath the Mn crusts (these smectites contain much higher Mn concentrations relative to deeper layers, but one cannot exclude some contamination by $\mathrm{Mn}$ oxides); (2) in some finegrained smectites from burrows mixed with pelagic ooze (Sample 509B-5-2, 35-37 cm [1]). Mn enrichment of pelagic oozes alternating with green clays and the low $\mathrm{Fe}_{2} \mathrm{O}_{3} / \mathrm{MnO}_{2}$ ratio $(0.5)$ in these sediments must also be noted (Samples 509B-5-2, 35-37 cm [2] and 509B-5-1, $86-90 \mathrm{~cm}$ ); (3) in the oxidized Fe-Mn sediments brown carbonate and siliceous ooze with $\mathrm{Fe}-\mathrm{Mn}$ nodules and crusts occur in the uppermost horizons of the mounds. We noted the similarity of the composition of micronodules separated from the uppermost mound sediments to the $\mathrm{Fe}-\mathrm{Mn}$ crusts and nodules from these oozes and to the carbonate-free basis composition of the uppermost pelagic sediments in the mounds. We therefore classified all these materials as "upper crusts" in contrast to "lower crusts" which occur farther down in the mound section and are characterized by a lower Fe-Mn ratio and by lower iron, silica, and alumina concentrations. The least differentiated type of Fe-Mn oxide sediments was sampled as a dark brown nonconsolidated mud in a layer of pelagic ooze (Sample 509B-2-3, 12-14 cm) within the unit of the hydrothermal sediments. The $\mathrm{Fe}_{2} \mathrm{O}_{3}$ / $\mathrm{MnO}_{2}$ ratio in the analyzed sample is approximately $1 / 2$.

In the pelagic oozes from the low heat-flow areas and the off-mounds sedimentary sections, higher $\mathrm{Fe}$ and $\mathrm{Mn}$ concentrations relative to normal oceanic carbonate sediments (Turekian and Wedepohl, 1961) are observed. Further, the $\mathrm{Fe}$ and $\mathrm{Mn}$ concentrations (on a carbonatefree basis) approach the $\mathrm{Fe}$ and $\mathrm{Mn}$ concentrations found in deep ocean red clays (Turekian and Wedepohl, 1961; Strakhov, 1976; Migdisov, Bogdanov et al., 1979). The highest concentrations of these elements, especially $\mathrm{Mn}$, are found in the upper oxidized surface layers of the pelagic sediments (Lynn and Bonatti, 1965). The layers of pelagic ooze occurring between hydrothermal layers or from lower in the mounds sections have relatively higher concentrations of $\mathrm{Mn}$ and $\mathrm{Fe}$ than do the off-mounds and low heat-flow, nonmounds, sedimentary sections (Tables 7-9).

At the same time, significant inhomogeneity of the elements in the pelagic ooze on the mounds (Tables 1-3) must be taken into account. For example, there are samples (e.g., Sample 509-2-2, 127-131 cm) with high concentrations of iron $\left(15 \% \mathrm{Fe}_{2} \mathrm{O}_{3}\right)$ with average or low concentrations of $\mathrm{Mn}(0.34 \% \mathrm{MnO})$, and there are other examples (e.g., Sample 509B-5-2, 35-37 cm [2]) where the concentrations of these elements run opposite: e.g., $11 \% \mathrm{MnO}$ and $5.76 \% \mathrm{Fe}_{2} \mathrm{O}_{3}$.

Iron in hydrothermal nontronitic smetites is mainly in an oxidized state (Rateev et al., 1980; Hoffert et al., 1980). However, the $\mathrm{FeO}$ concentrations in the smectites (Tables 1-3, 7-9) fluctuate from below the determina- 
Table 1. Major and minor elements in sediments from Hole 507D, DSDP Leg 70.

\begin{tabular}{|c|c|c|c|c|c|c|c|c|c|c|c|}
\hline Sample & $\begin{array}{c}1-1, \\
14-20 \mathrm{~cm}\end{array}$ & $\begin{array}{c}1-1, \\
18-20 \mathrm{~cm}\end{array}$ & $\begin{array}{c}2-1 \\
18-19 \mathrm{~cm}\end{array}$ & $\begin{array}{c}2-1 \\
22-26 \mathrm{~cm}\end{array}$ & $\begin{array}{c}2-1 \\
91-95 \mathrm{~cm}\end{array}$ & $\begin{array}{c}2-2 \\
6-10 \mathrm{~cm}\end{array}$ & $\begin{array}{c}4-2, \\
130-135 \mathrm{~cm}\end{array}$ & $\begin{array}{c}5-1, \\
78-80 \mathrm{~cm}\end{array}$ & $\begin{array}{c}6-3 \\
7-9 \mathrm{~cm}\end{array}$ & $\begin{array}{c}\text { 6-3, } \\
94-98 \mathrm{~cm}\end{array}$ & $\begin{array}{c}10-2, \\
116-119 \mathrm{~cm}\end{array}$ \\
\hline Component & no. 13 & no. 14 & no. 15 & no. 16 & no. 17 & no. 18 & no. 24 & no. 25 & no. 27 & no. 28 & no. 36 \\
\hline \multicolumn{12}{|c|}{ Major element oxides (\%) } \\
\hline $\mathrm{SiO}_{2}$ & & 21.5 & 2.5 & 48.95 & 52.1 & 53.4 & 53.65 & 57.30 & 52.7 & 18.7 & 8.65 \\
\hline $\mathrm{TiO}_{2}$ & & 0.17 & 0.07 & 0.05 & 0.08 & 0.08 & 0.09 & 0.41 & 0.07 & 0.13 & 0.11 \\
\hline $\mathrm{Al}_{2} \overline{\mathrm{O}}_{3}$ & & 3.10 & 0.51 & 0.85 & 0.52 & 0.65 & 0.38 & 10.68 & 0.35 & 1.98 & 1.55 \\
\hline $\mathrm{Fe}_{2} \mathrm{O}_{3}$ & 9.4 & 4.51 & 4.10 & 35.52 & 35.82 & 35.08 & 32.15 & 13,14 & 3296 & 9.16 & 2.52 \\
\hline $\mathrm{FeO}$ & & & & 0.42 & & 35.98 & 0.88 & 13.14 & 32.96 & 1.06 & 0.56 \\
\hline $\mathrm{MnO}$ & & $40.90^{\mathrm{a}}$ & $39.74^{\mathrm{a}}$ & 0.515 & 0.082 & 0.065 & 0.035 & 0.138 & 0.055 & 0.164 & 0.210 \\
\hline $\mathrm{MgO}$ & & 2.20 & 0.95 & 3.09 & 3.49 & 3.85 & 3.82 & 3.24 & 5.05 & 2.04 & 0.81 \\
\hline $\mathrm{CaO}$ & 3.8 & 8.48 & 2.32 & 0.51 & 0.32 & 0.35 & 0.23 & 1.16 & 0.38 & 33.47 & 46.18 \\
\hline $\mathrm{Na}_{2} \mathrm{O}$ & 2.2 & 1.53 & 4.26 & 1.32 & 2.51 & 1.83 & 1.12 & 2.20 & 1.51 & 0.26 & 0.30 \\
\hline $\mathrm{K}_{2} \mathrm{O}$ & & 0.82 & 0.37 & 1.36 & 1.34 & 1.29 & 3.16 & 2.61 & 2.37 & 0.50 & 0.34 \\
\hline $\mathrm{P}_{2} \mathrm{O}_{5}$ & & 0.210 & 0.224 & 0.096 & 0.069 & 0.081 & 0.058 & 0.112 & 0.078 & 0.102 & 0.066 \\
\hline $\mathrm{H}_{2} \mathrm{O}^{+}$ & & 5.05 & & 6.65 & & & 4.89 & & & 4.21 & 2.11 \\
\hline $\mathrm{CO}_{2}$ & & 12.14 & & 0.08 & & & & & & 26.68 & 35.93 \\
\hline Total & & 100.58 & & 99.41 & & & 100.46 & & & 98.46 & 99.34 \\
\hline \multicolumn{12}{|c|}{ Minor elements (ppm) } \\
\hline $\mathrm{Li}$ & 9 & 9 & & 10 & & & 6 & 40 & & 7.5 & 7.5 \\
\hline $\mathrm{Rb}$ & 5 & 8 & 6 & 25 & - & - & 62 & 90 & - & 18 & 9 \\
\hline Cs & - & 13.8 & 11.4 & - & - & - & 1.8 & 3.4 & - & - & 1.3 \\
\hline $\mathrm{Sr}$ & 705 & 545 & 300 & 104 & - & - & 36 & 270 & - & 1070 & 1496 \\
\hline Co & 24 & 25 & 10.5 & 3.6 & - & - & 0.6 & 12 & - & 4.7 & 4.9 \\
\hline $\mathrm{Ni}$ & 780 & 590 & 51 & 10 & - & - & 5 & 76 & 7.3 & 22 & 21 \\
\hline $\mathrm{Cr}$ & - & 26 & 40 & 31 & 10 & 10 & 20 & 37 & 20 & 21 & 28 \\
\hline V & - & 60 & 31 & - & - & - & - & 100 & - & - & - \\
\hline $\mathrm{Cu}$ & 185 & 170 & 44 & 36 & - & - & 5 & 153 & 14 & 50 & 51 \\
\hline $\mathrm{Zn}$ & 456 & 406 & 50 & 92 & - & - & 21 & 390 & 25 & 98 & 61 \\
\hline $\mathrm{Sb}$ & 18.7 & 12.2 & 11.7 & 1.2 & - & - & 1.0 & 1.8 & - & 0.6 & 0.5 \\
\hline $\mathrm{Pb}$ & 9 & 1.2 & $<0.5$ & 18 & - & - & $<0.5$ & - & 0.5 & - & - \\
\hline $\mathrm{Sc}$ & 2.8 & 7.1 & 1.7 & 2.8 & - & - & 1.0 & 12 & - & 4.7 & 3.1 \\
\hline $\mathrm{La}$ & 13 & 11.1 & 5.44 & 5.77 & - & - & 0.74 & 20.44 & - & 14.5 & 14.46 \\
\hline $\mathrm{Ce}$ & 12 & 13.8 & 4.6 & 5.6 & - & - & 1.47 & 33.52 & - & 9.6 & 10.05 \\
\hline Sm & 2.0 & 2.32 & 0.74 & 0.98 & - & - & 0.174 & 4.18 & - & 2.5 & 1.64 \\
\hline $\mathrm{Eu}$ & - & 0.390 & 0.270 & 0.444 & - & - & 0.107 & 0.963 & - & 0.64 & 0.369 \\
\hline $\mathrm{Tb}$ & - & 0.432 & 0.213 & - & - & - & 0.074 & 0.639 & - & - & 0.351 \\
\hline $\mathrm{Yb}$ & 2.0 & 1.690 & 0.560 & 0.947 & - & - & 0.213 & 1.933 & - & 1.330 & 1.113 \\
\hline Lu & - & 0.300 & 0.095 & 0.170 & - & - & 0.062 & 0.356 & - & 0.190 & 0.174 \\
\hline
\end{tabular}

${ }^{\text {a }}$ Expressed as $\mathrm{MnO}_{2}$.

tion limit to greater than $3 \%$. The highest $\mathrm{FeO}$ concentration is observed in a fine-grained smectite mixed with pelagic ooze. The fluctuation of $\mathrm{FeO}$ content in the smectites is not random but shows a distinct trend, increasing from the top to the bottom of the hydrothermal units. As shown in Figure 2, the degree of iron reduction in the smectites increases with depth in the cores. Comparing Figures 2 and 3, we can conclude that at the offmounds sites and in the low heat-flow areas, the increase in $\mathrm{FeO} / \mathrm{Fe}_{2} \mathrm{O}_{3}$ with depth is very similar to this ratio increase of the smectites in the mounds. The areas with high heat flow (Holes 509 and 509B) are assumed to have the greater gradient of $\mathrm{FeO} / \mathrm{Fe}_{2} \mathrm{O}_{3}$, with the ratio increasing with depth.

Elements that do not depend on the redox gradient also vary with depth in the mounds. For example, potassium content in smectites is shown versus depth in Figure 4. Average concentrations of the major elements in the smectites from the "upper," "middle," and "lower" parts of mounds hydrothermal units are given in Tables 7 and 8. Although such a division of the smec- tites into three groups is quite arbitrary and different limits for such division can be chosen, the increase in $\mathrm{K}_{2} \mathrm{O}$ with depth, along with changes in relative abundances of most of the major elements, suggests alteration in the compositions of the smectites.

XRD investigations of the smectite samples support the regularity of their alteration with depth. Rateev et al. (1980) have shown that the green hydrothermal clays are the K-Fe smectites close to nontronite. Smectite can be defined "as a mixed-layer mineral in which typically montmorillonitic spaces filled with hydroxyl ions alternate with spaces filled with potassium." The authors suggest that this may be the result of glauconitization or celadonitization by influence of hydrothermal solutions. Fe- and K-rich glauconite-like mica in variable proportions tends to occur in the later stages of these processes. Smectite samples analyzed in this work are characterized by higher $\mathrm{Fe}$ and $\mathrm{K}$ and lower $\mathrm{Al}$ content, with the lower smectites assumed to be in a higher level of celadonitization, as compared to the previously cited work. Hoffert et al. (1980) nevertheless concluded on 
Table 2. Major and minor elements in sediments from Holes 507F, 507C, and 507H, DSDP Leg 70.

\begin{tabular}{|c|c|c|c|c|c|c|c|c|c|}
\hline & \multicolumn{5}{|c|}{ Hole $507 \mathrm{~F}$} & \multicolumn{2}{|c|}{ Hole $507 \mathrm{C}$} & \multicolumn{2}{|c|}{ Hole $507 \mathrm{H}$} \\
\hline Sar & $\begin{array}{c}1-1 \\
5-7 \\
\end{array}$ & $\stackrel{2-1}{14-17} \mathrm{~cm}$ & $\begin{array}{c}2-2, \\
132-134 \mathrm{~cm}\end{array}$ & $\begin{array}{c}3-3 \\
41-45 \mathrm{~cm}\end{array}$ & $\begin{array}{c}6-3, \\
55-59 \mathrm{~cm}\end{array}$ & $\begin{array}{c}1-2 \\
59-62 \mathrm{~cm}\end{array}$ & $\begin{array}{c}1-4 \\
141-145 \mathrm{~cm}\end{array}$ & $\begin{array}{c}6-1 \\
53-55 \mathrm{~cm}\end{array}$ & $\begin{array}{c}6-8, \\
115-119 \mathrm{~cm}\end{array}$ \\
\hline Componer & no. 105 & no. 107 & no. 101 & no. 103 & no. 108 & no. 37 & no. 39 & no. 40 & no. 43 \\
\hline \multicolumn{10}{|c|}{ Major element oxides $(\%)$} \\
\hline $\mathrm{SiO}_{2}$ & 17.9 & 27.3 & 52.40 & 14.45 & 9.55 & 26.8 & 23.90 & 12.2 & 13.90 \\
\hline $\mathrm{TiO}_{2}$ & 0.13 & 0.21 & 0.07 & 0.12 & 0.11 & 0.12 & 0.18 & 0.18 & 0.26 \\
\hline $\mathrm{Al}_{2} \mathrm{O}_{3}$ & 2.50 & 4.14 & 0.41 & 2.11 & 2.00 & 2.12 & 3.98 & 2.18 & 4.02 \\
\hline $\mathrm{Fe}_{2} \mathrm{O}_{3}$ & 2.21 & 7.12 & 33.73 & 2.57 & 1.76 & 0.88 & 2.22 & 1.23 & 1.51 \\
\hline $\mathrm{FeO}$ & - & 7.12 & 0.33 & 0.70 & 0.58 & 0.62 & 0.97 & 0.72 & 0.99 \\
\hline $\mathrm{MnO}$ & $2.92^{\circ}$ & 0.279 & 0.030 & 0.278 & 0.146 & 0.341 & 0.240 & 0.138 & 0.172 \\
\hline $\mathrm{MgO}$ & 0.88 & 2.02 & 3.48 & 2.23 & 0.76 & 0.86 & 1.15 & 0.78 & 1.04 \\
\hline $\mathrm{CaO}$ & 36.75 & 29.58 & 0.18 & 41.09 & 44.61 & 33.87 & 34.63 & 42.85 & 41.79 \\
\hline $\mathrm{Na}_{2} \mathrm{O}$ & 0.64 & 0.89 & 1.14 & 0.33 & 0.27 & 0.38 & 0.55 & 0.23 & 0.56 \\
\hline $\mathrm{K}_{2} \mathrm{O}$ & 0.33 & 0.56 & 1.95 & 0.32 & 0.29 & 0.29 & 0.53 & 0.26 & 0.65 \\
\hline $\mathrm{P}_{2} \mathrm{O}_{5}$ & 0.125 & 0.119 & 0.050 & 0.074 & 0.078 & 0.080 & 0.085 & 0.078 & 0.112 \\
\hline $\mathrm{H}_{2} \mathrm{O}^{+}$ & 4.53 & - & 5.72 & 3.27 & 2.29 & 2.98 & 3.46 & 4.23 & 1.65 \\
\hline $\mathrm{CO}_{2}$ & 28.41 & - & - & 31.79 & 35.00 & 26.87 & 26.97 & 33.34 & 31.76 \\
\hline LOI & 1.02 & - & - & - & 1.43 & 3.00 & 1.78 & - & 1.04 \\
\hline Total & 98.34 & - & 99.49 & 99.33 & 98.87 & 99.21 & 100.64 & 98.42 & 99.45 \\
\hline \multicolumn{10}{|c|}{ Minor elements (ppm) } \\
\hline $\mathrm{Li}$ & 7 & 16 & 6 & 6 & 8 & - & 9 & 7.5 & 10 \\
\hline $\mathrm{Rb}$ & 9.5 & 17 & 42 & 11 & 9 & - & 13 & 9 & 14 \\
\hline Cs & 2.2 & - & 1.26 & - & 0.6 & - & 1.2 & - & 1.26 \\
\hline $\mathrm{Ba}$ & 129 & - & 90 & - & 148 & - & 79 & - & 125 \\
\hline $\mathrm{ST}_{\mathrm{T}}$ & 1201 & 980 & 37 & 410 & 1314 & 1010 & 1025 & 1258 & 1088 \\
\hline Co & 11 & 12 & 0.7 & 9 & 4.0 & 10 & 8.1 & 6.0 & 7.2 \\
\hline $\mathrm{Ni}$ & - & 190 & 4.8 & 107 & 21 & - & 134 & 66 & 52 \\
\hline $\mathrm{Cr}$ & 15 & - & 10 & - & 18 & - & 18 & - & 12 \\
\hline $\mathrm{Cu}$ & - & 23 & 19 & 76 & 50 & - & 96 & 65 & 57 \\
\hline $\mathrm{Zn}$ & 225 & 489 & 29 & 184 & 125 & - & 206 & 150 & 75 \\
\hline $\mathrm{Cd}$ & 0.057 & - & 0.27 & - & - & - & - & - & - \\
\hline $\mathrm{Sb}$ & 1.0 & - & 0.7 & - & 0.4 & 1.6 & 3.8 & - & 0.6 \\
\hline As & - & - & - & - & 3.1 & - & - & - & 9.3 \\
\hline $\mathrm{Pb}$ & - & 48 & $<0.5$ & 30 & 44 & - & 30 & - & - \\
\hline $\mathrm{Sc}$ & 4.8 & 7 & 0.7 & 3.8 & 3.3 & 4.8 & 5.7 & 4.5 & 6.8 \\
\hline $\mathrm{La}$ & 10.10 & 17.20 & 1.27 & - & 10.15 & 8.70 & 10.30 & - & 18.80 \\
\hline $\mathrm{Ce}$ & 6.28 & - & 11.90 & - & 8.80 & - & 7.52 & - & 15.02 \\
\hline $\mathrm{Sm}$ & 1.612 & 1.700 & 0.930 & 1.450 & 1.270 & 1.650 & 1.540 & 1.040 & 2.136 \\
\hline $\mathrm{Eu}$ & 0.432 & 0.450 & 0.214 & - & 0.301 & - & 0.501 & - & 0.553 \\
\hline $\mathrm{Tb}$ & 0.393 & - & 0.198 & - & 0.269 & - & 0.310 & - & 0.462 \\
\hline $\mathrm{Yb}$ & 1.270 & 1.300 & 0.451 & 1.360 & 1.274 & 1.040 & 1.300 & 1.130 & 1.404 \\
\hline $\mathrm{Lu}$ & 0.209 & - & 0.069 & - & 0.175 & - & 0.233 & - & 0.213 \\
\hline
\end{tabular}

a Expressed as $\mathrm{MnO}_{2}$.

the basis of X-ray diffractograms that the green clays had a smectite structure and contained a mica phase with a $d$-spacing equal to $10 \AA$.

Our XRD investigation has shown that the green clays are represented by mixed-layered minerals which contain a high iron (Fe-montmorillonite-nontronite series) three-layer structure. This conclusion is based on $d_{060}$ spacing values of diffractograms which vary from 1.502 to $1.505 \AA$ (Fig. 5). The ratio of the secondary reflection (002) of the smectite and the basal mica reflection (001) is significant. There is $80-90 \%$ smectite in the mixed-layer structure of Sample 66 which is from the upper smectite layers ( $2.8 \mathrm{~m}$ sub-bottom depth) of Sample 509-1-2, 126-129 cm. An equal and possibly greater smectite content is found in the upper green clay layers of Samples 507D-2-1, 22-26 cm and 91-95 cm (1.2-1.9 $\mathrm{m}$ sub-bottom depth). Approximately half as much smectite $(\mathbf{4 0 - 5 0 \% )}$ ) is found within the mica-smectite mineral from Hole 507D (Table 1: no. 24; Sample 507D 4-2, $130-135 \mathrm{~cm})$, which was sampled at 12.8 meters subbottom. The minimum content of smectite structures $(30-40 \%)$ and maximum mica-layer content are found in the deepest hydrothermal sediment layer at $19.6 \mathrm{me}-$ ters sub-bottom in Hole 509B. The structural alterations observed (Fig. 6) are in agreement with the increase of
$\mathrm{K}_{2} \mathrm{O}$ concentration with depth in the mounds sections from 1.3 to $5.0 \%$ (Fig. 4).

Some green clays from the mounds sections (Samples 507D-5-1, 78-80 cm and 509B-3-2, 104-109 cm) which alternated with pelagic-ooze layers differ significantly from the $\mathrm{Fe}$-rich and $\mathrm{Al}$-poor clays previously discussed. They have a higher concentration of $\mathrm{Al}$, and their compositions are close to that of a beidellite-nontronitic type of smectite.

As was noted previously (Honnorez et al., 1981) a distinct gradient change of amorphous $\mathrm{SiO}_{2}$ concentration with depth in all but Hole 509 and the off-mounds sections was observed. A typical example of the siliceous microfossil test distribution through the sedimentary sections is shown in Figure 7. It can be seen that these tests are lacking in the lower horizons of the mounds and that they are nearly absent in the hydrothermal units. At the same time, the concentrations of siliceous tests within the sediments does not differ with depth in the low heat-flow regions (Fig. 7). Their preservation here is much better than in the pelagic oozes found in the mounds areas. $\mathrm{CaCO}_{3}$, which is the main component in the pelagic sediments, is absent in greenclay layers (Tables 1-8). In addition, this mineral is observed only in fine-grained smectites which are mixed 
with pelagic oozes. Minor amounts of $\mathrm{C}_{\text {org }}$ and $\mathrm{S}_{\text {pyr }}$ are observed in the mixed layers, but they are practically absent in granular pure smectites.

One main peculiarity of the mounds hydrothermal sediments is that they are poor in alumina (Tables 7 and 8). Boström and Peterson (1969) have also reported aluminium-poor and $\mathrm{Fe}-\mathrm{Mn}$ rich metalliferous sediments in areas of high heat flow near mid-ocean rises. Aluminium is one of the most stable elements under sedimentary conditions, and the change in the ratios of various elements to alumina is used to estimate the input rate of sediments from hydrothermal sources. Comparison of the element ratios to alumina in the mounds and off the mounds to those which are not affected by hydrothermal solutions (Hole 508) may give a rough estimation of the elemental input from hydrothermal solutions and an approximate scale of the redistribution of the elements.

The results of this comparison show the distinct geochemical differences between hydrothermal sediments occurring at different levels within the mounds sections. The upper crusts differ from the lower crusts and from the $\mathrm{Fe}-\mathrm{Mn}$ oxide mud, but they have significant similarity to the uppermost oxidized layers of the off-mound pelagic oozes in the high heat-flow area (Fig. 8). The FeMn oxide sediments differ from all Mn-crusts and from oxidized off-mound oozes by their significant enrichment in $\mathrm{Fe}$ and $\mathrm{Si}$. At the same time all oxidized sediments of the high heat-flow area share a common peculiarity: They are strongly enriched in manganese in comparison with the low heat-flow area pelagic oozes. All the hydrothermal crusts are enriched in $\mathrm{Mn}, \mathrm{K}, \mathrm{Na}, \mathrm{Mg}$, and, in some cases, in $\mathrm{Fe}$ and $\mathrm{Si}$ (for the $\mathrm{Fe}-\mathrm{Mn}$ oxide sediment) relative to pelagic oozes.

The comparison of iron-rich smectites from different levels of the mounds sections with the mound pelagic oozes and the pelagic sediments from the low heat-flow area is shown in Figure 9. High ratios of $\mathrm{SiO}_{2}, \mathrm{Fe}_{2} \mathrm{O}_{3}$, $\mathrm{FeO}, \mathrm{K}, \mathrm{Na}$, and $\mathrm{Mg}$ to alumina in smectites are evident. There is also the enrichment in $\mathrm{Fe}_{2} \mathrm{O}_{3}$ and $\mathrm{K}$ in the mound pelagic oozes (both in basal sediments and in oozes alternating with smectites). A high manganese to alumina ratio is characteristic of pelagic oozes interlayering with hydrothermal sediments. The high alumina smectites, scattered as thin layers or patches in these pelagic oozes, are similar to the host sediments in elemental ratios, but they differ significantly from hydrothermal iron-rich and alumina-poor green clays. In other words, interpreting obtained data relative to the least mobile alumina, we can suggest significant input.

A more accurate estimation of elemental input or subtraction caused by hydrothermal activity can be obtained by evaluating the absolute masses of elements or oxides in the mound sequence with respect to those in the low heat-flow sedimentary sequences. In these estimates, the physical properties of sediments (porosity and density) which were ignored in calculations of ratios to alumina have to be considered.

Unfortunately, data on physical properties were not available for all samples analyzed; thus we used shipboard measurements for intervals close to the analyzed samples or average values for each type of sediment in the hole if physical properties had not been measured near our samples.

The results of the calculations are presented in Table 10. They show a high input of silica in the hydrothermal layers. The mass of silica in smectite is up to five times as large as in pelagic ooze found in the low heat-flow area. At the same time, silicon is depleted up to twothirds from the basal pelagic oozes in the mounds section. Silica flux is a maximum in the lower smectites and decreases in the upper smectite layers. The same trends exist for iron. Iron input in the lower smectites is 20 times higher than in pelagic sediments. Both ferric and ferrous iron supply is a maximum in these lower smectites. Estimates of iron mass in the mounds pelagic sediments show a distinct increase. As a rule, the iron increase in pelagic layers alternating with smectites is greater than in basal sediments. Within the smectites, alumina mass values differ from each other and from that of pelagics by a factor of three. In the upper smectites at Hole 509B, alumina mass values are the same as in pelagic sediments from low heat-flow areas. At the same time the middle and lower smectites in Hole 509B and all the smectites in Hole 507D are depleted in alumina masses respective to low heat-flow sediments. The variations of alumina masses in smectites presumably result both from the significant role of the pore infilling texture of smectites in some layers and from the inhomogeneity of alumina masses in parent pelagic oozes being replaced by smectite. Actually, pelagic ooze from the mounds sequences at Hole 507D contains only half as much alumina mass as low heat-flow pelagic sediments.

\section{MINOR ELEMENTS}

The distribution of minor elements and their relations with major elements in hydrothermal sediments differs from pelagic ooze.

As a rule, element concentrations in pelagic sediments are higher than in hydrothermal sediments, especially when values obtained are calculated on a carbonate-free basis (Tables 7-9). It can be shown that only the upper crust and $\mathrm{Fe}-\mathrm{Mn}$ oxide sediments are close to the pelagic sediments in some minor element concentrations. High alumina smectites also contain higher concentrations of minor elements when compared to the hydrothermal sediments.

Differences in relationships of elements are observed between pelagic and hydrothermal sediments. For example, in Figure 10 the $\mathrm{Mn}$ and Ni contents in the offmounds pelagic ooze show a nice correlation. This relationship is worse in mounds pelagic sediments and it is absent in hydrothermal smectites and Mn crusts. Similar trends exist between $\mathrm{Ni}$ plotted against $\mathrm{Sb}$ (Fig. 11). Correlations between $\mathrm{Ni}, \mathrm{Co}$, and $\mathrm{Cu}$ are observed in all the sediments. $\mathrm{Zn}$ correlates with $\mathrm{Fe}$ in Mn crusts (Fig. 12). The relationship between $\mathrm{K}$ and $\mathrm{Rb}$ within hydrothermal and pelagic sediments is shown in Figure 13. There is a nice correlation between these elements in pelagic oozes and in the smectites replacing them. In contrast, this correlation is absent in Mn crusts.

The average concentrations of rare-earth elements (REE) in hydrothermal sediments are one order of mag- 
Table 3. Major and minor elements in sediments from Hole 509B, Leg 70.

\begin{tabular}{|c|c|c|c|c|c|c|c|c|c|c|c|c|c|}
\hline Component & $\begin{array}{c}\begin{array}{c}1-1, \\
40-42 \mathrm{~cm}\end{array} \\
\text { no. } 96\end{array}$ & $\begin{array}{c}\begin{array}{c}1-1, \\
84-87 \mathrm{~cm}\end{array} \\
\text { no. } 99\end{array}$ & $\begin{array}{c}\begin{array}{c}1-1, \\
108-110 \mathrm{~cm}\end{array} \\
\text { no. } 64\end{array}$ & $\begin{array}{c}\begin{array}{c}1-2, \\
48-52 \mathrm{~cm}\end{array} \\
\text { no. } 65\end{array}$ & $\begin{array}{c}\begin{array}{c}1-2, \\
126-129 \mathrm{~cm}\end{array} \\
\mathrm{no} .66\end{array}$ & $\begin{array}{c}\begin{array}{c}2-1, \\
90-93 \\
\text { no. } 67\end{array} \\
\end{array}$ & $\begin{array}{c}2-1, \\
109-111 \mathrm{~cm}\end{array}$ & $\begin{array}{c}\begin{array}{c}2-1, \\
124-126 \mathrm{~cm}\end{array} \\
\text { no. } 100\end{array}$ & $\begin{array}{c}\begin{array}{c}2-2, \\
40-42 \mathrm{~cm}\end{array} \\
\text { no. } 69\end{array}$ & $\begin{array}{c}2-2, \\
112-115 \mathrm{~cm} \\
\text { no. } 70\end{array}$ & $\frac{\begin{array}{c}2-2, \\
127-131 \mathrm{~cm}\end{array}}{\text { no. } 71}$ & $\begin{array}{c}\begin{array}{c}2-3, \\
12-14 \mathrm{~cm}\end{array} \\
\text { no. } 97\end{array}$ & $\begin{array}{c}\begin{array}{c}2-3, \\
16-18 \mathrm{~cm}\end{array} \\
\text { no. } 72\end{array}$ \\
\hline \multicolumn{14}{|c|}{ Major element oxides (\%) } \\
\hline $\mathrm{SiO}_{2}$ & 3.9 & 17.3 & 10.5 & 1.5 & 50.8 & 16.4 & 6.4 & 49.50 & 45.10 & 51.9 & 35.55 & 32.75 & 23.65 \\
\hline $\mathrm{TiO}_{2}^{2}$ & 0.10 & 0.16 & 0.13 & 0.08 & 0.07 & 0.24 & 0.15 & 0.16 & 0.22 & 0.24 & 0.32 & 0.18 & 0.08 \\
\hline $\mathrm{Al}_{2} \mathrm{O}_{3}$ & 0.90 & 3.07 & 2.08 & 0.71 & 0.30 & 3.88 & 1.87 & 1.39 & 4.26 & 4.12 & 5.51 & 5.38 & 0.82 \\
\hline $\mathrm{Fe}_{2} \mathrm{O}_{3}$ & 0.91 & 3.70 & 5.46 & 0.56 & 34.20 & 4.00 & 1.69 & 29.10 & 23.02 & 28.4 & 9.33 & 3.03 & 17.76 \\
\hline $\mathrm{FeO}$ & - & - & - & - & - & - & - & - & - & - & 0.69 & 0.33 & - \\
\hline $\mathrm{MnO}$ & $47.97^{\mathrm{a}}$ & $9.81^{\mathrm{a}}$ & $36.08^{\mathrm{a}}$ & $78.34^{\mathrm{a}}$ & 1.16 & $34.76^{\mathrm{a}}$ & $42.15^{\mathrm{a}}$ & $4.06^{\mathrm{a}}$ & $9.88^{\mathrm{a}}$ & 0.270 & 0.220 & 0.705 & $35.00^{\mathrm{a}}$ \\
\hline $\mathrm{MgO}$ & 1.49 & 1.24 & 2.46 & 3.42 & 3.72 & 3.02 & 3.44 & 3.56 & 3.68 & 4.07 & 2.65 & 1.04 & 3.56 \\
\hline $\mathrm{CaO}$ & 3.61 & 32.7 & 15.76 & 1.68 & 0.23 & 9.35 & 6.53 & 0.88 & 0.74 & 1.00 & 21.4 & 28.24 & 3.88 \\
\hline $\mathrm{Na}_{2} \mathrm{O}$ & - & 0.71 & 1.27 & 1.53 & 1.24 & 1.16 & 1.05 & 0.94 & 1.21 & 1.58 & 0.91 & 1.21 & 1.29 \\
\hline $\mathrm{K}_{2} \mathrm{O}$ & 0.49 & 0.42 & 0.41 & 1.14 & 1.81 & 0.70 & 0.47 & 2.14 & 1.60 & 1.72 & 0.96 & 1.43 & 1.11 \\
\hline $\mathrm{P}_{2} \mathrm{O}_{5}$ & 0.105 & 0.147 & 0.186 & 0.118 & 0.073 & 0.160 & 0.130 & 0.065 & 0.129 & 0.115 & 0.110 & 0.090 & 0.187 \\
\hline $\mathrm{H}_{2} \mathrm{O}^{+}$ & - & 5.62 & - & 7.74 & 5.88 & - & - & 7.11 & 8.10 & - & 7.41 & 3.46 & 8.64 \\
\hline $\mathrm{CO}_{2}$ & - & 27.43 & - & 3.93 & n.d. & - & - & 0.68 & 1.69 & - & 14.91 & 20.33 & 4.43 \\
\hline L.O.I. & - & n.d. & - & n.d. & n.d. & - & - & n.d. & n.d. & - & n.d. & 1.81 & n.d. \\
\hline Total & - & 99.31 & - & 100.80 & 99.48 & - & - & 99.59 & 99.63 & - & 99.97 & 99.99 & 100.41 \\
\hline \multicolumn{14}{|c|}{ Minor elements (ppm) } \\
\hline $\mathrm{Li}$ & 1.9 & 8 & 5 & $<2$ & 5 & 6 & 10 & 11 & 15 & 15 & 20 & 9 & 8 \\
\hline $\mathrm{Rb}$ & 1.9 & 10 & 6 & 7 & 30 & 6 & 14 & 40 & 34 & 41 & 26 & 31 & 10 \\
\hline Cs & 7.7 & 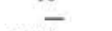 & - & 8.8 & & - & - & & 1.7 & - & - & 1.7 & - \\
\hline $\mathrm{Sr}$ & 890 & 2440 & 820 & 680 & 47 & 545 & 750 & 200 & 795 & 270 & 730 & 876 & 645 \\
\hline Co & 22 & 10 & - & 14 & 1.7 & 14 & 28 & - & 16 & - & - & 3.4 & 156 \\
\hline $\mathrm{Ni}$ & 146 & 144 & 175 & 60 & 5.5 & 132 & 153 & 12 & 48 & 14 & 88 & 53 & 840 \\
\hline $\mathrm{Cr}$ & 12 & 16 & 10 & - & 30 & 30 & 61 & 20 & 40 & 20 & - & 15 & 40 \\
\hline $\mathrm{Cu}$ & 50 & 152 & 144 & 27 & - & 70 & 122 & 61 & 130 & 50 & 78 & 48 & 321 \\
\hline $\mathrm{Zn}$ & 173 & 220 & 220 & 37 & 27 & 88 & 98 & 55 & 70 & 85 & 270 & 134 & 690 \\
\hline Sb & 15.4 & 10 & - & 10 & 0.5 & - & 8.2 & - & 1.9 & - & - & 0.9 & 25.2 \\
\hline $\mathrm{Pb}$ & $<15$ & 8.5 & 1.5 & $<1$ & 1.7 & $<1$ & $<1$ & 3.2 & 2.6 & $<0.5$ & - & 30 & $<1$ \\
\hline $\mathrm{Sc}$ & 6.5 & 4.5 & - & 1.6 & 0.5 & 3.5 & 10.4 & 3.4 & 8.2 & - & - & 5.6 & 6.2 \\
\hline $\mathrm{La}$ & 3. & 10.7 & - & 2.62 & 0.45 & 9.2 & - & 3.3 & 13.6 & - & - & 12.0 & 5.04 \\
\hline $\mathrm{Ce}$ & 3. & 9 & - & 3.5 & 0.88 & 10.0 & - & - & 16.3 & - & - & 11.4 & 4.52 \\
\hline Sm & 0.85 & 1.5 & - & 0.78 & 0.16 & 1.4 & - & 0.85 & 2.48 & - & - & 2.3 & 0.85 \\
\hline Eu & 0.299 & 0.43 & - & 0.167 & 0.033 & 0.44 & - & - & 0.572 & - & - & 0.572 & - \\
\hline $\mathrm{Tb}$ & 0.233 & 0.40 & - & 0.141 & 0.027 & 0.44 & - & - & 0.495 & - & - & 0.439 & - \\
\hline $\mathrm{Yb}$ & 0.805 & 1.2 & - & 0.437 & 0.087 & 1.5 & - & - & 1.504 & - & - & 1.274 & 0.612 \\
\hline $\mathrm{Lu}$ & 0.134 & 0.18 & - & 0.063 & 0.017 & - & - & - & 0.296 & - & - & 0.218 & 0.090 \\
\hline
\end{tabular}

${ }^{a} \mathrm{Mn}$ and $\mathrm{MnO}_{2}$.

nitude less than their average concentrations in carbonate-free pelagic ooze material (Tables 7 and 8). For minimal concentrations of REE in hydrothermal smectites, they differ by about two orders of magnitude. The REE distribution pattern in pelagic ooze and hydrothermal sediments as a rule is much the same. The main difference is the cerium deficiency. This peculiarity reflects the role of seawater in the REE pattern of this sediment formation (Piper, 1974; Piper and Graef, 1974; Bender et al., 1971; Migdisov, Bogdanov et al., 1979). Smectites containing the lowest REE concentration are characterized by different patterns (Figs. 14, 15). They are similar to basalt REE distribution patterns and are close to the smectite found in veins and in basalt alteration zones (Fig. 16) recovered from the deep part of Hole 504B, Costa Rica Rift and described by Sharaskin et al. (in press). These patterns are assumed to be caused by hydrothermal solutions circulating through the basalts.

The minor element concentrations in the mounds sediments are localized at different depths in much the same manner as the major element distributions-for example, in the upper layer of the mounds sediments in Hole 507D are concentrated sufficiently higher amounis of $\mathrm{Ni}, \mathrm{Co}, \mathrm{Cu}, \mathrm{Zn}, \mathrm{Pb}$, and $\mathrm{REE}$ as compared with the lower Mn crusts. These concentrations also approach the values found in the upper oxidized layer of pelagic ooze (Tables 7 and 8).

The distribution of minor elements in the smectites also varies with depth. $\mathrm{Rb}$ content increases from the top to the bottom of the hydrothermal unit in the mounds sections. Figure 17 plots zinc content against ferrous iron, which also increases with depth. It should be mentioned that higher concentrations of $\mathrm{Zn}$, as well as sulfide sulfur, occurred in smectites mixed with pelagic ooze. It is these varieties of smectite, characterized by higher concentrations of these minor elements, which are enriched in the pelagic sediments (Tables 1, 3, 7, and $8)$. Their concentrations in mixed smectites are intermediate between pure smectite and pelagic sediments.

In a number of cases the data on minor element distribution present evidence for redistribution of elements near the contact between smectite and pelagic sediment. For example, in Hole 509B, a smectite-infilled burrow surrounded by pelagic ooze was studied (Table 3; Sample 509B-5-2, 35-37 cm). Enrichment of iron, manganese $(3 \% \mathrm{MnO})$, and a high concentration of $\mathrm{Ni}(600$ $\mathrm{ppm}$ ) in the smectite was observed with more than $30 \%$ $\mathrm{CaCO}_{3}$. On a carbonate-free basis, $\mathrm{Zn}$ and $\mathrm{Cu}$ content in the pelagic ooze near the contact with smectite is three to four times and Ni concentration is nearly one-tenth as large as in the smectites. Enrichment of $\mathrm{Co}, \mathrm{Sb}$, and REE near the contact between the smectites and pelagic ooze was also observed.

Inhomogeneity of minor element distribution in the pelagic ooze interlayers within hydrothermal zones and in the lower pelagic ooze units also suggests a redistribution of elements. For example, Ni content in the mounds pelagic ooze differs from 5 to $180 \mathrm{ppm}$ (on a 
Table 3. (Continued).

\begin{tabular}{|c|c|c|c|c|c|c|c|c|c|c|c|c|c|}
\hline $\begin{array}{c}3-1, \\
86-89 \mathrm{~cm}\end{array}$ & $\begin{array}{c}3-2, \\
104-109 \mathrm{~cm}\end{array}$ & $\begin{array}{l}3-3 \\
17-22 \mathrm{~cm}\end{array}$ & ${ }_{46-51}^{4-1} \mathrm{~cm}$ & $\begin{array}{l}4-2, \\
98-103 \mathrm{~cm}\end{array}$ & $\begin{array}{c}4-3 \\
21-26 \mathrm{~cm}\end{array}$ & $\begin{array}{c}5-1 \\
86-90 \mathrm{~cm}\end{array}$ & $\stackrel{5-2}{35-37 \mathrm{~cm}(1)}$ & ${ }_{35-37}^{5-2} \mathrm{~cm}$ (2) & $\begin{array}{c}5-3 \\
80-82 \mathrm{~cm}\end{array}$ & $\begin{array}{c}6-3 \\
35-37 \mathrm{~cm}\end{array}$ & $\begin{array}{c}7-2 \\
70-74 \mathrm{~cm}\end{array}$ & $\begin{array}{c}8-1 \\
93-98 \mathrm{~cm}\end{array}$ & $\begin{array}{c}8-3 \\
52-78 \mathrm{~cm}\end{array}$ \\
\hline no. 73 & no, 74 & no. 75 & no. 98 & no. 76 & no. 77 & no. 78 & no. 79 & no. 80 & no. 81 & no. 82 & no. 83 & no. 84 & no. 85 \\
\hline 52.45 & 53.25 & 53.10 & 52.80 & 54.10 & 53.15 & 10.0 & 33.75 & 10.50 & 47.85 & 8.80 & 11.15 & 13.85 & 11.75 \\
\hline 0.08 & 0.42 & 0.08 & 0.08 & 0.23 & 0.08 & 0.10 & 0.11 & 0.16 & 0.08 & 0.06 & 0.18 & 0.22 & 0.20 \\
\hline 0.45 & 7.68 & 0.69 & 0.60 & 3.29 & 0.22 & 1.30 & 1.54 & 2.14 & 1.00 & 1.85 & 2.77 & 3.28 & 2.30 \\
\hline 32.10 & 19.66 & 31.06 & 31.98 & 26.40 & 32.10 & 1.19 & 16.56 & 1.37 & 26.91 & 1.07 & 1.43 & 2.01 & 1.73 \\
\hline- & 0.85 & 0.85 & 0.56 & - & - & - & 0.94 & 0.39 & 1.70 & 0.39 & 0.50 & 0.46 & 0.97 \\
\hline 0.530 & 0.212 & 0.068 & 0.224 & 0.065 & 0.058 & $2.070^{\mathrm{a}}$ & $3.255^{\mathrm{a}}$ & $2.690^{\mathrm{a}}$ & 0.072 & 0.550 & 0.240 & 0.232 & 0.245 \\
\hline 3.92 & 4.64 & 3.98 & 3.82 & 4.38 & 4.22 & 0.92 & 3.67 & 1.09 & 4.44 & 0.88 & 0.88 & 1.30 & 1.29 \\
\hline 0.54 & 0.98 & 0.33 & 0.36 & 0.85 & 0.29 & 45.27 & 17.32 & 42.66 & 4.46 & 46.67 & 44.14 & 41.44 & 44.46 \\
\hline 1.01 & 1.10 & 1.03 & 0.86 & 0.75 & 0.86 & 0.17 & 0.55 & 0.32 & 0.73 & 0.27 & 0.28 & 0.36 & 0.30 \\
\hline 2.98 & 1.94 & 3.38 & 3.20 & 2.69 & 2.74 & 0.15 & 2.35 & 0.28 & 4.63 & 0.36 & 0.36 & 0.43 & 0.32 \\
\hline 0.048 & 0.125 & 0.065 & 0.030 & 0.080 & 0.034 & 0.075 & 0.060 & 0.084 & 0.050 & 0.080 & 0.097 & 0.108 & 0.090 \\
\hline 6.13 & 7.26 & 5.81 & 5.85 & 6.50 & 5.91 & 2.17 & 4.63 & 2.84 & 5.64 & 1.68 & 2.54 & 4.06 & 2.56 \\
\hline 0.26 & n.d. & 0.19 & 0.21 & n.d. & n.d. & 35.10 & 14.84 & 33.54 & 3.24 & 37.17 & 33.31 & 30.69 & 33.86 \\
\hline n.d. & 0.53 & n.d. & n.d. & n.d. & n.d. & - & - & 0.83 & - & - & 0.53 & 0.53 & - \\
\hline 100.50 & 98.65 & 100.64 & 100.57 & 99.34 & 99.66 & 98.52 & 100.02 & 98.89 & 100.80 & 99.83 & 98.41 & 98.97 & 100.08 \\
\hline 3 & 26 & 9 & 5 & 11 & $<12$ & 6 & 13 & 9 & 13 & 5 & 7 & - & - \\
\hline 59 & 50 & 70 & 75 & 65 & 60 & 5 & 78 & 10 & 115 & 12 & 11 & - & 11 \\
\hline- & - & - & - & - & - & - & - & - & - & - & - & - & - \\
\hline 51 & 440 & 64 & 60 & 345 & 47 & 1470 & 530 & 1480 & 223 & 459 & 1464 & - & 1022 \\
\hline 4 & 8 & - & - & - & 3.8 & $<5$ & 16 & 12.5 & 4.8 & 3.7 & 5,8 & - & 9.3 \\
\hline 11 & 50 & 8 & $<5$ & 6 & 6.4 & 125 & 635 & 68 & 50 & $<5$ & 180 & - & 7.0 \\
\hline 10 & 48 & 30 & 30 & 33 & - & - & 10 & - & 10 & 3 & 18.4 & - & 42 \\
\hline 24 & 126 & 11 & 7.5 & 66 & 15 & 83 & 81 & 89 & 54 & 28 & 97 & - & 50 \\
\hline 24 & 217 & 21 & 32 & 53 & 19 & 160 & 168 & 175 & 104 & 48 & 223 & - & 118 \\
\hline- & 1.0 & - & - & - & 0.7 & - & 2.0 & 1.6 & 1.0 & - & - & - & 0.4 \\
\hline 1.0 & 0.9 & $<0.5$ & - & 0.8 & $<0.5$ & - & - & - & 1.9 & 30 & 30 & - & 33 \\
\hline 1.0 & - & - & - & 7.8 & 0.7 & - & 2.6 & 5 & 4.0 & 1.8 & 4.8 & - & 6.3 \\
\hline- & 10.5 & - & - & 7.0 & - & - & 7.0 & 10.9 & 2.22 & 11.07 & 14 & - & 12.3 \\
\hline- & 7.8 & - & - & 10 & - & - & - & 9.5 & 3.18 & 3.93 & 15.7 & - & 9.6 \\
\hline- & 2.81 & - & - & 1.9 & - & - & 1.1 & 2.0 & 0.655 & 1.75 & 3.5 & - & 1.97 \\
\hline- & 0.655 & - & - & - & - & - & - & 0.42 & - & - & 0.67 & - & 0.484 \\
\hline- & 0.552 & - & - & - & - & - & - & - & - & 0.293 & - & - & 0.418 \\
\hline- & 1.387 & - & - & - & - & - & 0.96 & 1.27 & 0.383 & 1.283 & 1.9 & - & 1.364 \\
\hline- & 0.238 & - & - & - & - & - & - & - & 0.091 & 0.086 & 0.30 & - & 0.222 \\
\hline
\end{tabular}

Table 4. Major and minor elements in sediments from Hole 509, DSDP Leg 70.

\begin{tabular}{|c|c|c|c|c|c|c|c|c|}
\hline Component & $\begin{array}{c}1-1 \\
4-7 \mathrm{~cm}\end{array}$ & $\begin{array}{c}\begin{array}{c}1-1, \\
82-86 \mathrm{~cm}\end{array} \\
\text { no. } 48\end{array}$ & $\frac{\begin{array}{c}\text { 3-1, } \\
50-52 \mathrm{~cm}\end{array}}{\text { no. } 44}$ & $\begin{array}{c}\begin{array}{c}4-1, \\
80-84 \mathrm{~cm}\end{array} \\
\text { no. } 49\end{array}$ & $\begin{array}{c}\begin{array}{c}5-1, \\
85-89 \mathrm{~cm}\end{array} \\
\text { no. } 50\end{array}$ & $\begin{array}{c}\begin{array}{c}\text { 6-1, } \\
91-95 \mathrm{~cm}\end{array} \\
\text { no. } 51\end{array}$ & $\begin{array}{c}\begin{array}{c}7-2, \\
62-66 \mathrm{~cm}\end{array} \\
\text { no. } 52\end{array}$ & $\frac{\begin{array}{c}8-2 \\
19-21 \mathrm{~cm}\end{array}}{\text { no. } 53}$ \\
\hline \multicolumn{9}{|c|}{ Major element oxides (\%) } \\
\hline $\mathrm{SiO}_{2}$ & 18.10 & 18.50 & 23.60 & 21.20 & 15.1 & 13.1 & 11.3 & 12.10 \\
\hline $\mathrm{TiO}_{2}$ & 0.16 & 0.12 & 0.26 & 0.18 & 0.18 & 0.15 & 0.17 & 0.17 \\
\hline $\mathrm{Al}_{2} \mathrm{O}_{3}$ & 2.93 & 1.73 & 3.69 & 3.54 & 2.38 & 2.37 & 1.96 & 2.92 \\
\hline $\mathrm{Fe}_{2} \mathrm{O}_{3}$ & 2.22 & 2.52 & 1.86 & 2.46 & 1.38 & 1.08 & 0.78 & 1.49 \\
\hline $\mathrm{FeO}$ & - & 0.70 & 0.76 & 0.79 & 0.68 & 0.80 & 0.68 & 0.60 \\
\hline $\mathrm{MnO}$ & 5.130 & 0.288 & 0.484 & 1.420 & 0.346 & 0.311 & 0.203 & 0.194 \\
\hline $\mathrm{MgO}$ & 0.86 & 1.12 & 1.21 & 1.36 & 0.91 & 0.87 & 0.75 & 0.78 \\
\hline $\mathrm{CaO}$ & 35.23 & 38.23 & 34.98 & 34.64 & 41.16 & 42.51 & 43.67 & 42.86 \\
\hline $\mathrm{Na}_{2} \mathrm{O}$ & 0.52 & 0.31 & 0.48 & 0.53 & 0.35 & 0.37 & 0.41 & 0.33 \\
\hline $\mathrm{K}_{2} \mathrm{O}$ & 0.35 & 0.27 & 0.42 & 0.46 & 0.32 & 0.28 & 0.26 & 0.33 \\
\hline $\mathrm{P}_{2} \mathrm{O}_{5}$ & 0.139 & 0.130 & 0.100 & 0.089 & 0.085 & 0.108 & 0.090 & 0.178 \\
\hline $\mathrm{H}_{2} \mathrm{O}^{-}+$ & 5.32 & 3.77 & 4.63 & 3.63 & 4.90 & 3.31 & 2.74 & 2.98 \\
\hline $\mathrm{CO}_{2}$ & 28.58 & 30.19 & 27.33 & 27.78 & 32.43 & 32.98 & 33.54 & 33.68 \\
\hline L.O.1. & - & 0.86 & 0.22 & - & - & - & 2.17 & - \\
\hline Total & 99.54 & 98.74 & 100.02 & 98.08 & 100.22 & 98.24 & 98.72 & 98.61 \\
\hline \multicolumn{9}{|c|}{ Minor elements (ppm) } \\
\hline $\mathrm{Li}$ & 10 & 8 & 10 & 12 & 8 & 9 & 8 & 10 \\
\hline $\mathrm{Rb}$ & 9 & 15 & 14 & 23 & 10 & 10 & 9.5 & 10 \\
\hline Cs & & 2.3 & & & & & & 1.1 \\
\hline $\mathrm{Ba}$ & & 90 & & & & & & 151 \\
\hline $\mathrm{Sr}$ & 1160 & 1120 & 1180 & 1200 & 1290 & 1460 & 1460 & 1460 \\
\hline Co & 25 & 8.0 & 7.5 & 9 & 5 & 5 & 10.7 & 7.5 \\
\hline $\mathrm{Ni}$ & 245 & 111 & 145 & 165 & 105 & 82 & 77 & 67 \\
\hline $\mathrm{Cr}$ & & 24 & & 21.6 & 15 & 15 & 13 & 19 \\
\hline v & & & & 16 & & & & \\
\hline $\mathrm{Cu}$ & 124 & 105 & 106 & 122 & 84 & 72 & 120 & 105 \\
\hline $\mathrm{Zn}$ & 220 & 220 & 193 & 185 & 175 & 170 & 126 & 93 \\
\hline $\mathrm{Sb}$ & 3.3 & 1.0 & & & & & 1.7 & 0.3 \\
\hline $\mathrm{Sc}$ & 6.4 & 2.8 & & 5,2 & & & 5.0 & \\
\hline La & 12.7 & 11.03 & & 10.7 & & & 7.7 & 8.17 \\
\hline $\mathrm{Ce}$ & 11.8 & 7.19 & & 8.6 & & & 7.9 & 6.70 \\
\hline $\mathrm{Sm}$ & 2.4 & 1.722 & & 1.7 & & & 1.6 & 1.41 \\
\hline Eu & - & 0.357 & & 0.4 & & & 0.4 & 0.355 \\
\hline $\mathrm{Tb}$ & 0.25 & 0.323 & & 0.4 & & & 0.4 & \\
\hline $\mathrm{Yb}$ & 1.24 & 1.313 & & 1.6 & & & 1.46 & 1.042 \\
\hline
\end{tabular}


Table 5. Major and minor elements in sediments from Holes 508 and 508C, DSDP Leg 70.

\begin{tabular}{|c|c|c|c|c|c|c|c|c|c|c|c|c|}
\hline \multirow{3}{*}{ Component } & \multicolumn{10}{|c|}{ Hole 508} & \multicolumn{2}{|c|}{ Hole $508 \mathrm{C}$} \\
\hline & $\begin{array}{c}1-1, \\
39-43 \mathrm{~cm}\end{array}$ & $\begin{array}{c}2-1, \\
61-65 \mathrm{~cm}\end{array}$ & $\begin{array}{c}3-1 \\
123-127 \mathrm{~cm}\end{array}$ & $\begin{array}{c}4-2, \\
80-84 \mathrm{~cm}\end{array}$ & $\begin{array}{c}5-1 \\
82-86 \mathrm{~cm}\end{array}$ & $\begin{array}{c}6-2, \\
25-29 \mathrm{~cm}\end{array}$ & $\begin{array}{c}7-2 \\
123-128 \mathrm{~cm}\end{array}$ & $\begin{array}{c}8-2, \\
33-35 \mathrm{~cm}\end{array}$ & $\begin{array}{c}8-3 \\
54-56 \mathrm{~cm}\end{array}$ & $\begin{array}{c}8-3, \\
63-64 \mathrm{~cm}\end{array}$ & $\begin{array}{c}1-1, \\
24-28 \mathrm{~cm}\end{array}$ & $\begin{array}{c}1-2, \\
15-19 \mathrm{~cm}\end{array}$ \\
\hline & no. 1 & no. 2 & no. 3 & no. 4 & no. 5 & no. 6 & no. 7 & no. 8 & no. 9 & no. 10 & no. 11 & no. 12 \\
\hline \multicolumn{13}{|c|}{ Major element oxides ( $\%)$} \\
\hline $\mathrm{SiO}_{2}$ & 17.8 & 27.5 & 19.4 & 21.8 & 12.7 & 9.7 & 16.20 & 18.65 & 14.0 & 17.6 & 8.3 & 7.8 \\
\hline $\mathrm{TiO}_{2}$ & 0.12 & 0.19 & 0.19 & 0.12 & 0.15 & 0.13 & 0.14 & 0.16 & 0.13 & 0.13 & 0.13 & 0.13 \\
\hline $\mathrm{Al}_{2} \mathrm{O}_{3}$ & 1.81 & 4.71 & 3.75 & 2.42 & 2.37 & 2.01 & 2.63 & 3.25 & 2.20 & 2.25 & 1.89 & 1.71 \\
\hline $\mathrm{Fe}_{2} \mathrm{O}_{3}$ & 3.11 & & & & 1.24 & 1.21 & 1.14 & 2.52 & 1.58 & 1.16 & 1.94 & 2.71 \\
\hline $\mathrm{FeO}$ & 0.60 & 2.21 & 2.58 & 1.71 & 0.42 & $\int 1.21$ & 0.49 & 0.70 & 0.54 & 0.71 & 0.41 & \\
\hline $\mathrm{MnO}$ & 0.312 & 0.921 & 0.378 & 0.282 & 0.388 & 0.249 & 0.180 & 0.173 & 0.153 & 0.140 & 0.214 & 0.226 \\
\hline $\mathrm{MgO}$ & 1.33 & 1.01 & 1.01 & 0.84 & 0.83 & 0.62 & 0.84 & 1.44 & 1.23 & 4.47 & 1.62 & 1.84 \\
\hline $\mathrm{CaO}$ & 37.92 & 31.95 & 38.09 & 37.56 & 43.70 & 47.77 & 41.88 & 37.33 & 44.61 & 41.64 & 45.79 & 47.84 \\
\hline $\mathrm{Na}_{2} \mathrm{O}$ & 0.29 & 0.60 & 0.60 & 0.43 & 0.42 & 0.32 & 0.36 & 0.35 & 0.87 & 0.26 & 0.15 & 0.20 \\
\hline $\mathrm{K}_{2} \mathrm{O}$ & 0.26 & 0.91 & 0.45 & 0.32 & 0.30 & 0.29 & 0.34 & 0.41 & 0.13 & 0.04 & 0.27 & 0.31 \\
\hline $\mathrm{P}_{2} \mathrm{O}_{5}$ & 0.099 & 0.116 & 0.116 & 0.096 & 0.106 & 0.114 & 0.099 & 0.104 & 0.100 & 0.103 & 0.122 & 0.166 \\
\hline $\mathrm{H}_{2} \mathrm{O}^{+}$ & 3.13 & 3.50 & 3.0 & 3.02 & 2.75 & 0.50 & 2.55 & 3.43 & 0.65 & 1.65 & 1.71 & 0.5 \\
\hline $\mathrm{CO}_{2}$ & 29.22 & 25.20 & 30.0 & 29.56 & 34.45 & 37.60 & 31.49 & 28.07 & 30.69 & 27.47 & 35.62 & 37.37 \\
\hline LOĨ & 3.56 & & & 0.66 & & & 1.71 & 2.21 & 3.07 & 1.30 & 1.33 & \\
\hline Total & 98.92 & 98.82 & 99.57 & 98.82 & 99.67 & 100.51 & 100.05 & 98.79 & 99.95 & 98.92 & 99.49 & 100.81 \\
\hline \multicolumn{13}{|c|}{ Minor elements (ppm) } \\
\hline $\mathrm{Li}$ & 7.5 & & & 7.2 & & & 9.5 & 5 & 3 & 16 & 6 & \\
\hline $\mathrm{Rb}$ & 7 & & & 8.5 & & & 10 & 11 & 4 & 2.5 & 6 & \\
\hline $\mathrm{Cs}$ & 2.0 & & & & & & & & & & 0.9 & \\
\hline $\mathrm{Ba}$ & 100 & & & & & & & & & 82 & 51 & \\
\hline $\mathrm{Sr}$ & 1130 & & & 1260 & & & 1190 & 1120 & 1170 & 1130 & 780 & \\
\hline Co & 10 & & & 10 & & & 5.5 & 6.0 & 6.5 & 5.5 & 3.6 & \\
\hline $\mathrm{Ni}$ & 143 & & & 116 & & & 78 & 86 & 55 & 52 & 30 & \\
\hline $\mathrm{Cr}$ & 18.5 & & & & & & & 15.2 & & 12.6 & 8.5 & \\
\hline $\mathrm{Cu}$ & 118 & & & 97 & & & 77 & 87 & 15 & 6 & 49 & \\
\hline $\mathrm{Zn}$ & 215 & & & 174 & & & 139 & 189 & 85 & 38 & 48.5 & \\
\hline $\mathrm{Sb}$ & 1.2 & & & & & & & 1.7 & & 0.8 & & \\
\hline $\mathrm{Sc}$ & 4 & & & 4 & & & 3.8 & 4.9 & 2.3 & 4.5 & 3.0 & \\
\hline $\mathrm{La}$ & 7.8 & & & 11.2 & & & 9.4 & 7.0 & 10.3 & 11.0 & 6.3 & \\
\hline $\mathrm{Ce}$ & 9.0 & & & & & & & & & 8.9 & 4.6 & \\
\hline $\mathrm{Sm}$ & 1.559 & & & 2.0 & & & 1.63 & 2.5 & 2.5 & 1.416 & 1.086 & \\
\hline $\mathrm{Eu}$ & 0.309 & & & & & & & & & 0.468 & & \\
\hline $\mathrm{Tb}$ & & & & & & & & & & 0.290 & 0.242 & \\
\hline $\mathrm{Yb}$ & 0.907 & & & 1.67 & & & & & 1.63 & 1.222 & 0.851 & \\
\hline $\mathrm{Lu}$ & 0.234 & & & & & & & & & 0.240 & 0.171 & \\
\hline
\end{tabular}

carbonate-free basis [CFB], Ni content $=31-798 \mathrm{ppm}$ ), Co concentration varies from 4.6 to $58 \mathrm{ppm}(28-257$ on CFB), and zinc ranges from 48 to $223 \mathrm{ppm}$ (295-989 on CFB). In all but the Mn-rich oxidized layers of the mounds sediments, the distribution of the elements is more homogeneous and varies more than two to four times. The most homogeneous distribution of minor elements is in the off-mounds area and in the low heat-flow areas.

The increase in the homogenization of elements in the pelagic oozes from the mounds to the off-mounds and to the low heat-flow areas is attributed to the decreased influence of hydrothermal activity.

Data on minor element to alumina ratios (Figs. 8, 9) and the absolute masses of minor elements in the smectites and the pelagic oozes (Table 10) suggest an increase and redistribution of a number of elements within the sediments studied. There are significant concentration increases in $\mathrm{Ni}, \mathrm{Co}, \mathrm{Zn}, \mathrm{Sb}, \mathrm{Cu}$, and $\mathrm{Cs}$ relative to alumina in the upper manganese crusts (Fig. 8) in comparison with pelagic ooze from the low heat-flow areas. Elements concentrated in minor amounts in the oxidized pelagic ooze layer $(\mathrm{Li}, \mathrm{Rb}$, and $\mathrm{Cr}$ ) and REE to alumina ratios are close to low heat-flow area sediments.
In the lower crusts the list of enriched elements is clearly different. $\mathrm{Rb}$ and $\mathrm{Cr}$ are enriched relative to alumina while the transition, rare-earth elements, and $\mathrm{Sc}$ are not.

The Fe-Mn oxide sediments have a significant enrichment in $\mathrm{Ni}, \mathrm{Co}, \mathrm{Zn}$, and $\mathrm{Cu}$ relative to alumina as well as upper crusts and oxidized layers, but higher ratios of $\mathrm{Rb}$ and $\mathrm{Cr}$ to alumina are observed when comparing $\mathrm{Fe}$ Mn oxide sediments to the pelagic oozes.

Minor element to alumina ratios (Fig. 9) and mass calculations (Table 10) in the smectites indicate a great increase of $\mathrm{Li}, \mathrm{Rb}, \mathrm{Cs}$, and $\mathrm{Sb}$ in these sediments. Depletion of $\mathrm{Sr}, \mathrm{Ni}, \mathrm{Co}, \mathrm{Cu}$, and $\mathrm{Zn}$ in mounds sediments are noted and observed both in the smectites and in the pelagic oozes which alternate with smectites. Redistribution and local fluctuations of these elements are observed in the smectites which are mixed with pelagic oozes and in the basal pelagic oozes.

\section{CONCLUSIONS}

Some conclusions follow from the data that we have presented:

1) Mn crusts and alumina-poor and iron-rich smectites differ in major and minor element distribution 
Table 6. Major and minor elements in sediments from Hole 510, DSDP Leg 70.

\begin{tabular}{|c|c|c|c|c|}
\hline Component & $\begin{array}{c}\begin{array}{c}2-2, \\
145-149 \mathrm{~cm}\end{array} \\
\text { no. } 54\end{array}$ & $\begin{array}{c}\begin{array}{c}2-6, \\
80-84 \mathrm{~cm}\end{array} \\
\text { no. } 56\end{array}$ & $\begin{array}{c}\begin{array}{c}5-5, \\
133-137 \mathrm{~cm}\end{array} \\
\text { no. } 60\end{array}$ & $\begin{array}{c}\begin{array}{c}8-2, \\
73-78 \mathrm{~cm}\end{array} \\
\text { no. } 63\end{array}$ \\
\hline \multicolumn{5}{|c|}{ Major element oxides (\%) } \\
\hline $\mathrm{SiO}_{2}$ & 27.05 & 20.6 & 23.40 & 23.6 \\
\hline $\mathrm{TiO}_{2}$ & 0.11 & 0.13 & 0.10 & 0.12 \\
\hline $\mathrm{Al}_{2} \mathrm{O}_{3}$ & 2.10 & 2.50 & 1.23 & 2.49 \\
\hline $\mathrm{Fe}_{2} \mathrm{O}_{3}$ & 0.96 & 0.95 & 0.29 & 0.76 \\
\hline $\mathrm{FeO}$ & 0.61 & 0.55 & 0.61 & 0.53 \\
\hline $\mathrm{MnO}$ & 0.225 & 0.201 & 0.100 & 0.158 \\
\hline $\mathrm{MgO}$ & 0.94 & 0.69 & 0.46 & 1.05 \\
\hline $\mathrm{CaO}$ & 35.10 & 38.74 & 39.21 & 37.33 \\
\hline $\mathrm{Na}_{2} \mathrm{O}$ & 0.32 & 0.47 & 0.29 & 0.32 \\
\hline $\mathrm{K}_{2} \mathrm{O}$ & 0.31 & 0.38 & 0.20 & 0.27 \\
\hline $\mathrm{P}_{2} \mathrm{O}_{5}$ & 0.102 & 0.116 & 0.040 & 0.170 \\
\hline $\mathrm{H}_{2} \mathrm{O}^{+}$ & 3.31 & 2.71 & 2.90 & 2.81 \\
\hline $\mathrm{CO}_{2}$ & 27.13 & 30.68 & 30.78 & 28.62 \\
\hline LOI & 1.04 & 0.72 & 0.60 & 1.50 \\
\hline Total & 99.31 & 99.44 & 100.21 & 99.73 \\
\hline \multicolumn{5}{|c|}{ Minor elements (ppm) } \\
\hline $\mathrm{Li}$ & 12.5 & 9 & 6.5 & 22 \\
\hline $\mathrm{Rb}$ & 14 & 12.5 & 6.5 & 10 \\
\hline Cs & 1.2 & - & - & 0.9 \\
\hline $\mathrm{Sr}$ & 1090 & 1250 & 1200 & 1190 \\
\hline Co & 8 & 6.7 & 5.2 & 5.9 \\
\hline $\mathrm{Ni}$ & 132 & 74 & 51 & 45 \\
\hline $\mathrm{Cr}$ & 16 & - & - & 14.2 \\
\hline $\mathrm{Cu}$ & 81 & 74 & 77 & 63 \\
\hline $\mathrm{Zn}$ & 198 & 136 & 93 & 106 \\
\hline $\mathrm{Sb}$ & 1.0 & - & - & 0.5 \\
\hline $\mathrm{Sc}$ & 4 & 5.5 & 3.4 & 3.7 \\
\hline $\mathrm{La}$ & 10.1 & 16.4 & 9.8 & 7.6 \\
\hline $\mathrm{Ce}$ & 5.9 & - & - & 6.2 \\
\hline $\mathrm{Sm}$ & 1.112 & 3.2 & 2.3 & 1.77 \\
\hline Eu & 0.265 & - & - & 0.411 \\
\hline $\mathrm{Tb}$ & 0.276 & - & - & 0.358 \\
\hline $\mathrm{Yb}$ & 0.850 & 1.76 & 1.4 & 1.074 \\
\hline $\mathrm{Lu}$ & 0.135 & - & - & 0.181 \\
\hline
\end{tabular}

from the pelagic sediments and surely have a different origin, but both must be attributed to hydrothermal activity.

2) A significant additional input of a number of elements ( $\mathrm{Si}, \mathrm{Fe}, \mathrm{Mn}, \mathrm{K}, \mathrm{Rb}, \mathrm{Li}$, etc.) to the mounds location are evident. There is a strong similarity between this list of elements and those that enriched the thermal solution sampled at the axis zone of Galapagos Rift (Edmond, Measures; McDuff, 1979; Edmond, Measures, Mangum, 1979).

3) The data strongly suggest interaction of pelagic ooze with hydrothermal solutions. This interaction leads to intensive redistribution of elements and to subtraction of some elements from mounds sediments $(\mathrm{Ni}, \mathrm{Co}$, $\mathrm{Cu}, \mathrm{REE}, \mathrm{Sr}$, etc.). These are the elements that are depleted in thermal solutions from the axis zone of Galapagos Rift.

4) Hydrothermally derived solutions rich in elements appear to differentiate in the mound section. This may result from a redox gradient encountered during the upward percolation of hydrothermal solutions through the sediment cover.
5) The similarities in element distribution between upper $\mathrm{Mn}$ crusts and $\mathrm{Fe}-\mathrm{Mn}$ oxides and the off-mounds upper oxidized layers of pelagic oozes (enrichment of $\mathrm{Ni}$, $\mathrm{Co}, \mathrm{Cu}, \mathrm{Zn}$, etc.) reflect the influence of seawater on their composition.

In light of the foregoing disscussion, it appears that the mounds form as the result of percolating solutions rich in $\mathrm{Si}, \mathrm{Fe}$, and $\mathrm{Mn}$ which emanate from the basement through fracture zones and react with seawater and with the overlying sediment layer. Available data give us no opportunity to resolve the problem of whether the input of iron was synchronous with that of manganese or whether the elements arrived separately. A great deal of data indicate a manganese influx to the water column above the Galapagos Spreading Center (Bolger et al., 1978; Lyle, 1976; Klinkhammer et al., 1977; Edmond et al., 1979 a,b). At the same time observations show that significant iron input also takes place and that $\mathrm{Fe}$ and $\mathrm{Mn}$ fractionation occurs during oxidation in the seawater (Gordeev et al., 1979).

The occurrence of the Fe-Mn oxide sediment in the mounds sections is assumed to reflect incomplete separation of these elements, and the correlation of the redox gradient with $\mathrm{Mn}$ and $\mathrm{Fe}$ separation suggests the possibility of synchronous iron and manganese input.

Data on different ferrous iron masses at different levels in the mounds section show that iron arrives at these levels in solution and is incompletely oxidized. This assumption agrees well with data from Edmond et al. on the composition of hydrothermal solutions from the axis of the Galapagos Rift. From the data presented above and other work (Honnorez et al., 1981), it appears that infiltration of oxygen-bearing waters into a mound is one of the main oxidizing factors. Proton formation and carbonate dissolution follow from the reaction of ferrous iron oxidation and its combination with $\mathrm{SiO}_{2}$ and $\mathrm{H}_{2} \mathrm{O}$. It is obvious that carbonate dissolution leads to a largescale redistribution of elements. It is likely that most dissolved and redistributed elements are washed out of mounds sediments by circulating water. Large amounts of oxygen are required for the precipitation of manganese in the form of todorokite, which was, fixed in the course of manganese and iron separation in the upper layers of the mounds sequence. The uppermost crusts in oxidized pelagic ooze, which were subjected to contact with seawater, have a similar elemental pattern as the pelagic oxidized layer. In contrast, the lower manganese crusts have the characteristics of rapidly accumulating manganese formations (Moor and Vogt, 1976) and are similar to the smectites from the standpoint of minor element distribution. Fe-Mn oxide sediment is assumed to have accumulated rapidly as a result of the simultaneous oxidation of both elements. Its composition demonstrates seawater influence. Direct deposition of this sediment from open seawater is possible.

Comparison of the different types of Galapagos hydrothermal mounds sediments with other products of hydrothermal activity in oceans and ophiolite zones of continents is interesting. The distribution of REE, reflecting the influence of different source material, can be chosen for this comparison. In Figure 16 is shown 
Table 7. Average composition of hydrothermal and pelagic sediments (carbonate-free basis) in mounds and off-mounds sedimentary sections, Site 507.

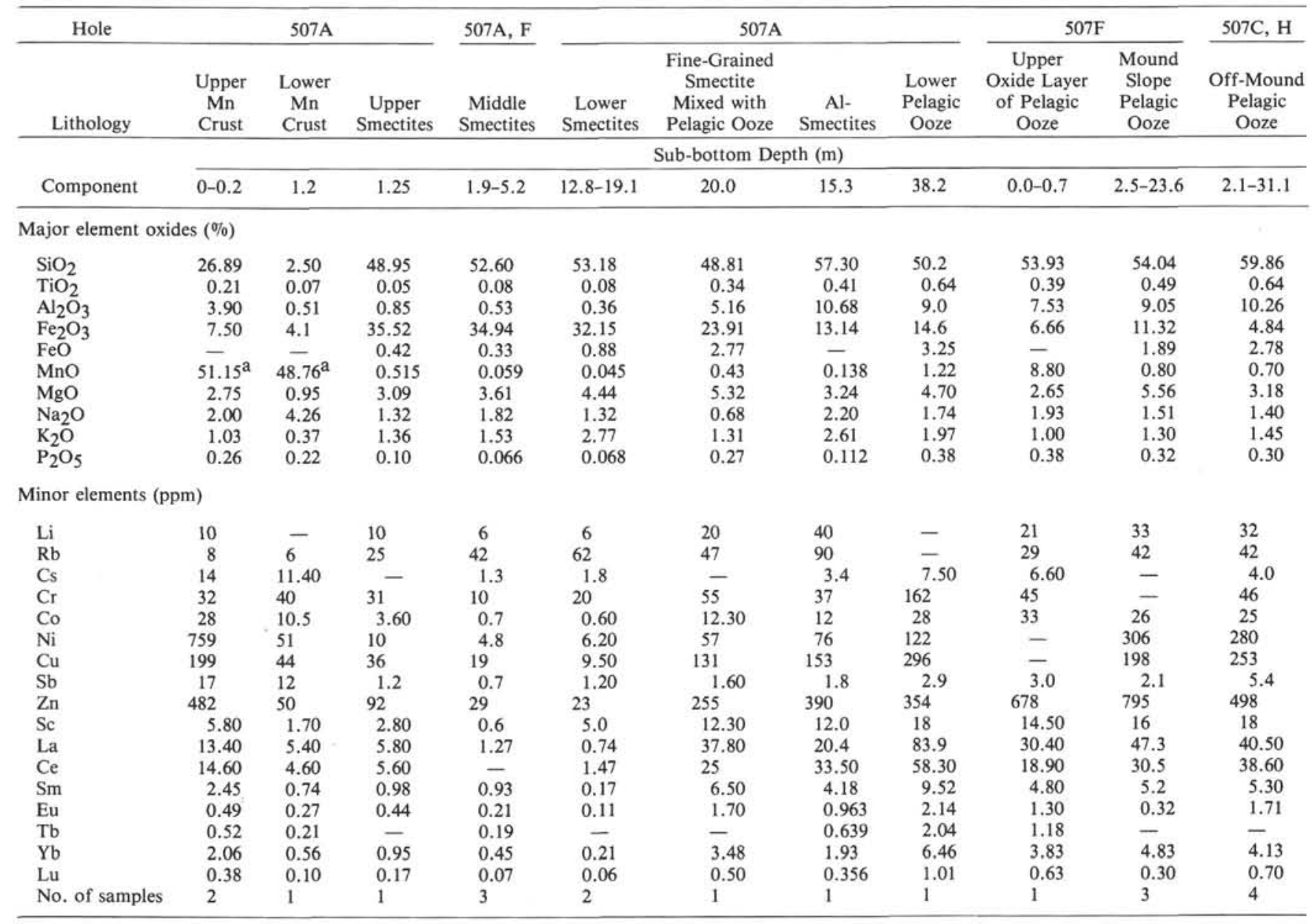

${ }^{\text {a }} \mathrm{Mn}$ as $\mathrm{MnO}_{2}$.

North American shale normalized REE distributions in hydrothermal products. The lowest concentrations of REE are characteristic of both vein smectites from basaltic basement and some samples of Galapagos mound smectites. REE patterns of this product are shown in Figure 16 (no. 1 and 3 ) and are assumed to be attributable to the hydrothermal source which produces these minerals. The same relationships are typical for some oceanic and ophiolitic formations (Fig. 16, no. 2, 4). These formations do not have any REE additions from the depositional environment. In contrast, the interaction of hydrothermally derived formations during their deposition with the surrounding environments tends to change initial REE distribution. For example, much of Galapagos hydrothermal smectites as well as lower manganese crusts have distinct cerium depletion and slight increases in REE concentrations (Fig. 16, no. 5-7). In the upper crusts of the Galapagos mounds, REE concentrations are further increased and the pattern of their distribution demonstrates a further similarity with seawater (Fig. 16, no. 9). The same concentrations and patterns in REE (Fig. 16, no. 8) were observed in the hydro- thermal pyrite that was oxidized by seawater near the Mid-Atlantic Ridge (Bonatti, Honnorez-Guerstein et al., 1976).

The maximum REE content and the typical seawater distribution pattern are reported from the East Pacific Rise metalliferous sediments and Cyprus ochres and umbers (Piper and Graef, 1974; Piper, 1974; Robertson and Fleet, 1976), which are supposed to be precipitated directly from open seawater (Fig. 16, no. 10,11).

It appears that hydrothermally derived sediments from active ocean zones are close to ophiolitic zones in REE distribution. It is also suggested that the interaction of hydrothermal solutions with the surrounding environments (e.g., seawater, pore water, sediments) leads to the increase in REE concentration in the resulting products and to changes in the initial REE distribution patterns.

This comparison also suggests that both replacement of sediments and minor scale infilling of voids without significant interaction with the sediments has taken place during the formation of smectite in the Galapagos mounds. 
Table 8. Average composition of hydrothermal and pelagic sediments (carbonate-free basis) in mounds and off-mounds sedimentary sections, Site 509.

\begin{tabular}{|c|c|c|c|c|c|c|c|c|c|c|c|c|}
\hline \multirow[b]{2}{*}{ Lithology } & \multicolumn{10}{|c|}{ Hole 509B } & \multicolumn{2}{|c|}{ Hole 509} \\
\hline & $\begin{array}{l}\text { Upper } \\
\text { Mn } \\
\text { Crust }\end{array}$ & $\begin{array}{c}\text { Lower } \\
\text { Mn } \\
\text { Crust }\end{array}$ & $\begin{array}{l}\text { Fe-Mn } \\
\text { Oxide } \\
\text { Sediment }\end{array}$ & $\begin{array}{c}\text { Upper } \\
\text { Smectites }\end{array}$ & $\begin{array}{c}\text { Middle } \\
\text { Smectites }\end{array}$ & $\begin{array}{c}\text { Lower } \\
\text { Smectites }\end{array}$ & $\begin{array}{c}\text { Fine- } \\
\text { Grain } \\
\text { Mixed } \\
\text { Smectites }\end{array}$ & $\begin{array}{c}\text { Al- } \\
\text { Smectites }\end{array}$ & $\begin{array}{c}\text { Pelagic } \\
\text { Ooze in } \\
\text { Hydrothermal } \\
\text { Unit }\end{array}$ & $\begin{array}{c}\text { Lower } \\
\text { Pelagic } \\
\text { Ooze }\end{array}$ & $\begin{array}{c}\text { Oxidized } \\
\text { Pelagic } \\
\text { Ooze }\end{array}$ & $\begin{array}{c}\text { Off-Mound } \\
\text { Pelagic } \\
\text { Ooze }\end{array}$ \\
\hline & \multicolumn{12}{|c|}{ Sub-bottom Depth (m) } \\
\hline Component & $0-1.20$ & $1.20-2.70$ & 6.16 & $2.7-5.6$ & $8.2-11.8$ & $12.2-20.0$ & 18.1 & 9.2 & $5.8-18.1$ & $23.0-33.0$ & 0.09 & $5.9-29$ \\
\hline \multicolumn{13}{|c|}{ Major element oxides $(\%)$} \\
\hline $\mathrm{SiO}_{2}$ & 14.40 & 1.55 & 23.65 & 51.35 & 52.78 & 52.68 & 49.75 & 53.45 & 57.67 & 52.74 & 55.84 & 57.28 \\
\hline $\mathrm{TiO}_{2}$ & 0.21 & 0.08 & 0.08 & 0.16 & 0.08 & 0.12 & 0.16 & 0.42 & 0.49 & 0.70 & 0.42 & 0.69 \\
\hline $\mathrm{Al}_{2} \mathrm{O}_{3}$ & 3.12 & 0.71 & 0.82 & 2.21 & 0.57 & 1.28 & 2.27 & 7.68 & 9.29 & 11.43 & 7.00 & 10.28 \\
\hline $\mathrm{Fe}_{2} \mathrm{O}_{3}$ & 3.71 & 0.50 & 17.76 & 29.68 & 31.40 & 29.34 & 24.41 & 19.66 & 9.68 & 6.97 & 7.26 & 5.39 \\
\hline $\mathrm{FeO}$ & - & - & - & - & 0.85 & 1.19 & 1.39 & 0.85 & 1.22 & 3.03 & 1.16 & 2.71 \\
\hline $\mathrm{MnO}$ & $55.37^{\mathrm{a}}$ & $78.34^{\mathrm{a}}$ & $35.00^{\mathrm{a}}$ & 0.72 & 0.30 & 0.106 & 4.754 & 0.212 & 3.69 & 1.86 & 11.93 & 1.62 \\
\hline $\mathrm{MgO}$ & 3.08 & 3.42 & 3.56 & 3.90 & 3.95 & 4.22 & 5.41 & 4.64 & 3.69 & 5.09 & 3.05 & 3.46 \\
\hline $\mathrm{Na}_{2} \mathrm{O}$ & 1.97 & 1.48 & 1.29 & 1.41 & 1.02 & 0.82 & 0.81 & 1.10 & 1.69 & 1.43 & 1.24 & 1.52 \\
\hline $\mathrm{K}_{2} \mathrm{O}$ & 0.66 & 1.14 & 1.11 & 1.76 & 3.18 & 3.40 & 3.46 & 1.94 & 1.84 & 1.76 & 0.94 & 1.27 \\
\hline $\mathrm{P}_{2} \mathrm{O}_{5}$ & 0.192 & 0.118 & 0.187 & 0.094 & 0.056 & 0.049 & 0.088 & 0.125 & 0.23 & 0.446 & 0.41 & 0.42 \\
\hline \multicolumn{13}{|c|}{ Minor elements (ppm) } \\
\hline $\mathbf{L i}$ & 8.1 & $<2$ & 8 & 10 & 6 & 10 & 19 & 26 & 30 & 31.7 & 27 & 36 \\
\hline $\mathbf{R b}$ & 10 & 7 & 10 & 36 & 64 & 81 & 115 & 50 & 42 & 57.5 & 38 & 45 \\
\hline Cs & 7.7 & - & - & - & - & - & - & - & 3.3 & - & 7.6 & 5.0 \\
\hline $\mathrm{Cr}$ & 46 & 70 & 40 & 25 & 20 & 25 & 15 & 48 & 36 & 98 & 79 & 64 \\
\hline Co & 23.8 & 14 & 156 & - & 4 & $<3.7$ & 23.6 & 6.4 & 28.9 & 109 & 48 & 28 \\
\hline $\mathrm{Ni}$ & 198 & 60 & 840 & 9.8 & 9.5 & $<17$ & 93.6 & 50 & 296 & 336 & 526 & 377 \\
\hline $\mathrm{Cu}$ & 143 & 27 & 321 & 50 & 18 & 35.6 & 119 & 126 & 256 & 277 & 346 & 382 \\
\hline $\mathrm{Sb}$ & 14.8 & 9 & 25.2 & 0.5 & - & 0.85 & 2.9 & 1.0 & 4.2 & 1.8 & 6.2 & 4.6 \\
\hline $\mathrm{Zn}$ & 211 & 37 & 690 & 56 & 22 & 52 & 248 & 217 & 480 & 610 & 671 & 482 \\
\hline $\mathrm{Sc}$ & 8.2 & 1.6 & 6.2 & 1.0 & 6.0 & 4.2 & 3.8 & 11 & 13.2 & 21.4 & 13.6 & 19.6 \\
\hline $\mathrm{La}$ & 13.6 & 5.3 & 5.0 & 0.5 & - & 4.6 & 10.3 & 10.5 & 44.4 & 59.9 & 36 & 34.3 \\
\hline $\mathrm{Ce}$ & 12.5 & 4.99 & 4.52 & 0.84 & - & 6.6 & - & 7.8 & 41.1 & 44.8 & 28.4 & 30.4 \\
\hline Sm & 2.11 & 1.1 & 0.85 & 0.14 & - & 1.28 & 1.60 & 2.81 & 8.40 & 11.8 & 6.2 & 6.2 \\
\hline Eu & 0.64 & 0.107 & - & 0.033 & - & - & - & 0.655 & 2.08 & 2.11 & 1.29 & 1.54 \\
\hline $\mathrm{Tb}$ & 0.59 & 0.141 & - & 0.06 & - & - & - & 0.552 & 1.59 & 1.87 & 0.88 & 1.57 \\
\hline $\mathrm{Yb}$ & 1.99 & 0.503 & 0.61 & 0.135 & - & 0.74 & 1.42 & 1.39 & 4.88 & 7.45 & 3.90 & 5.35 \\
\hline Lu & 0.29 & 0.061 & 0.09 & - & - & 0.133 & - & 0.238 & 1.09 & 0.66 & 0.62 & 1.02 \\
\hline No. of samples & 5 & 1 & 1 & 2 & 2 & 4 & 2 & 1 & 4 & 3 & 2 & 6 \\
\hline
\end{tabular}

${ }^{\mathrm{a}} \mathrm{Mn}$ as $\mathrm{MnO}_{2}$.

\section{ACKNOWLEDGMENTS}

The authors gratefully acknowledge Drs. P. Borella, J. Honnorez, Yu. Balashov, and G. Zakariadze for discussions and critical reviews. We also express our appreciation to Rosemary Amidei and Drs. P. Borella and A. Sharaskin for their invaluable assistance in improving the English version of this manuscript.

\section{REFERENCES}

Bender, M., Broecker, W., Gornitz, V., et al., 1971. Geochemistry of three cores from the East Pacific Rise. Earth Planet. Sci. Lett., 12: 425-433.

Bogdanov, Ju. A., Lisitzin, A. P., and Migdisov, A. A., 1979. O genezise metallonosnich osadkov. In Smirnov V. I. (Ed.), Metallonosnye Osadki Yugo-Vostochnoi Chasti Tihogo Okeana: Moscow (Nauka), pp. 249-276.

Bolger, G. V., Betzer, P. R., and Gordeev, V. V., 1978. Hydrothermally derived manganese suspended over the Galapagos Spreading Center. Deep-Sea Res., 25:721-733.

Bonatti, E., 1975. Metallogenesis at oceanic spreading centers. Ann. Rev. Earth Planet. Sci., 3:401-431.

Bonatti, E., Honnorez-Guerstein, M., Honnorez, J., and Stern, C., 1976. Hydrothermal pyrite concentrations from the Romanche Trench: Metallogenesis in oceanic spreading centers. Earth Planet. Sci. Lett., 32:1-10.

Bonatti, E., Zerbi, M., Kay, R., et al., 1976. Metalliferous deposits from the Appennine ophiolites: Mesozoic equivalents of modern deposits from oceanic spreading centers. Bull. Geol. Soc. Am., 87: 83-94.

Boström, K., and Petersen, M., 1969. The origin of aluminium-poor ferro-manganoan sediments in areas of high heat-flow on the East Pacific Rise. Mar. Geol., 7:427-447.
Corliss, J., Dymond, J. R., Gordon, L., et al., 1979. Submarine thermal springs on the Galapagos Rift. Science, 203:1073-1083.

Cronan, D., 1976. Basal metalliferous sediments from the Eastern Pacific. Bull. Geol. Soc. Am., 87:928-934.

Dymond, J., Corliss, J., Cobler, R., et al., 1980. Composition and origin of sediments recovered by deep drilling of sediment mounds. In Rosendahl, B. R., Hekinian, R., et al., Init. Repts. DSDP, 54: Washington (U.S. Govt. Printing Office), 377-385.

Edmond, J., Measures, C., McDuff, R., et al., 1979. Ridge crest hydrothermal activity and the balances of the major and minor elements in the ocean: The Galapagos data. Earth Planet. Sci. Lett., 46:1-18.

Edmond, J., Measures, C., Mangum, B., et al., 1979. On the formation of metal-rich deposits at ridge crests. Earth Planet. Sci. Lett., 46:19-30.

Gordeev, V. V., Demina, L. L., and Konkin, A. M., 1979. Jelezo i marganetc gidrotermalnogo proishojdenija $\mathrm{v}$ glubinnich vodach Tihogo Okeana (Galapagosskaja aktivnaja zona, depressija Hessa). In Smirnov, V. I. (Ed.), Metallonosnye Osadki Jugo-Vostochnoy Chasti Tihogo Okeana: Moscow (Nauka), pp. 224-236.

Gradusov, B. P., 1971. Zavisimost mejdu znachenijami d/n bazalnih refleksov i sogerjanijami slyudistih paketov v smeshannosloinih obrazovanijah slyudo-smektitovogo tipa. Litologia i Poleznie Iskopaemie, 6:152-155.

Hekinian, R., Rosendahl, B., Cronan, D., et al., 1978. Hydrothermal deposits and associated basement rocks from the Galapagos Spreading Center. Oceanol. Acta, 1:473-482.

Hoffert, M., Perseil, A., Courtois, C., et al., 1980. Sedimentology, mineralogy and geochemistry of hydrothermal and sedimentary deposits from Holes 424, 424A, 424B, 424C. In Rosendahl, B. R., Hekinian, R., et al., Init. Rept. DSDP, 54: Washington (U.S. Govt. Printing Office), pp. 339-376. 
Hoffert, M., Perseil, A., Hekinian, R., Choukroune, P., et al., 1978. Hydrothermal deposits sampled by diving saucer in transform fault "A" near $37^{\circ} \mathrm{N}$ on the Mid-Atlantic Ridge, FAMOUS area. Oceanol. Acta, 1:73-86.

Honnorez, J., Von Herzen, R. P., Barrett, T. J., Becker, K., Bender, M. L., Borella, P. E., Hubberten, H.-W., Jones, S. C., Karato, S., Laverne, C., Levi, S., Migdisov, A., Moorby, S., Schrader, E. L., et al., 1981. Hydrothermal mounds and young ocean crust of the Galapagos: Preliminary Deep Sea Drilling results, Leg 70. Bull. Geol. Soc. Am., 92:457-472.

Klinkhammer, J., Bender, M., and Weiss, R. F., 1977. Hydrothermal manganese in the Galapagos Rift. Nature, 269(5626):319-320.

Lonsdale, P., 1977. Deep-tow observations at the mounds abyssal hydrothermal field, Galapagos Rift. Earth Planet. Sci. Lett., 36, 92-110.

Lyle, M., 1976. Estimation of hydrothermal manganese input to the oceans. Geology, 4(12):733-736.

Lynn, D., and Bonatti, E., 1965. Mobility of manganese in diagenesis of deep sea sediments. Mar. Geol., 3:457-474.

Migdisov, A. A., Bogdanov, Y. A., Lisitzin, A. P., et al., 1979. Geohimija metallonosnyh osadkov. In Smirnov, V. I. (Ed.), Metallonosnye Osadki Yugo-Vostochnoi Chasti Tihogo Okeana: Moscow (Nauka), pp. 122-200.

Migdisov, A. A., Girin, Yu, P., Galimov, E. M., et al., 1980. Major and minor elements and sulphur isotopes on the Mesozoic and Cenozoic sediments at Sites 415 and 416, Leg 50, DSDP. In Lancelot, Y., Winterer, E. L., et al., Init. Repts. DSDP, 50: Washington (U.S. Govt. Printing Office), 675-689.

Migdisov, A. A., Miklishansky, A. Z., Saveliev, B. V., et al., 1980. Neutron activation analysis of rare earth elements and some trace elements in volcanic ashes and pelagic clays, DSDP, Leg 59. In Kroenke, L., Scott, R., et al., (Ed.), Init. Repts. DSDP, 59: Washington (U.S. Govt. Printing Office), 653-668.

Moor, W. S., and Vogt, P. R., 1976. Hydrothermal manganese crusts from two sites near the Galapagos Spreading Axis. Earth Planet. Sci. Lett., 29:349-356.

Natland, J., Rosendahl, B., Hekinian, R., et al., 1979. Galapagos hydrothermal mounds: Stratigraphy and chemistry revealed by deep sea drilling. Science, 204:613-616.

Piper, D. Z., 1974. Rare earth elements in ferromanganese nodules and other marine phases. Geochim. Cosmochim. Acta, 38: 1007-1022.

Piper, D. Z., and Graef, P., 1974. Gold and rare-earth elements in sediments from the East Pacific Rise. Mar. Geol., 17:287-297.

Piper, D. Z., Veeh, H., Bertrand, W., et al., 1975. An iron-rich deposit from the north-east Pacific. Earth Planet. Sci. Lett., 26: 114-120.

Rateev, M., Timofeev, P., and Rengarten, N., 1980. Minerals of the clay fraction in Pliocene-Quaternary sediments of the East Equatorial Pacific. In Rosendahl, B. R., Hekinian, R., et'al., Init. Repts. DSDP, 54: Washington (U.S. Govt. Printing Office), 307-318.

Robertson, A., and Fleet, A., 1976. The origin of rare earth in metalliferous sediments of the Troodos Massif, Cyprus. Earth Planet. Sci. Lett., 28:385-394.

Rosendahl, B., Hekinian, R., et al., 1980. Init. Repts. DSDP: Washington (U.S. Govt. Printing Office).

Sayles, F., and Bischoff, J., 1973. Ferromanganoan sediments in the Equatorial East Pacific Rise. Earth Planet. Sci. Lett., 19:330-336.

Schrader, E., Rosendahl, B., Furbish, W., and Mattey, D., 1980. Mineralogy and geochemistry of hydrothermal and pelagic sediments from the mounds hydrothermal field, Galapagos Spreading Center, DSDP, Leg 54. J. Sediment. Petrol., 50:917-928.
Sclater, J., and Klitgord, K., 1973. A detailed heat flow topographic and magnetic survey across Galapagos Spreading Center, at 86 W. J. Geophys. Res., 78:6951-6975.

Sedyh, E. M., and Beliaev, Yu. I., 1980. Ustranenie vliyania osnovi pri elektrotermicheskom atomno-absorbcionnom opredelenii $\mathrm{Pb}$. Ag. Jurnal Analiticheskoj Himii, 12:2348.

Sharaskin, A. Ya., Migdisov, A. A., Rostshina, I. A., Miklishansky, A. Z., in press. Major and trace element chemistry of the Hole 504B basalts and their alteration products (Costa-Rica Rift, DSDP, Leg 70). In Cann, J. R., Langseth, M. G., Honnorez, J., Von Herzen, R. P., White, S. M., et al., Init. Rept. DSDP, 69: Washington (U.S. Govt. Printing Office).

Strakhov, N. M., 1976. Problemi Sovremennogo Okeanicheskogo Litogeneza, Trudy GIN (Vol. 292): Moscow (Nauka).

Turekian, K., and Wedepohl, K., 1961. Distribution of the elements in some major units of the earth crust. Bull. Geol. Soc. Am., 72:175-192.

Table 9. Average composition of pelagic sediments from low heat-flow areas (carbonate-free basis).

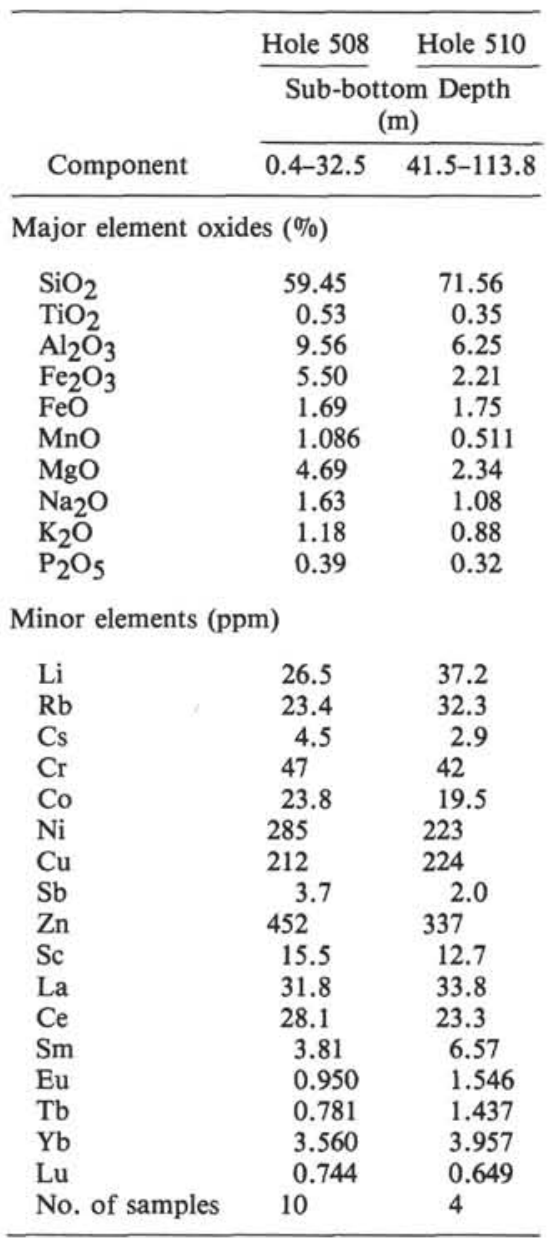




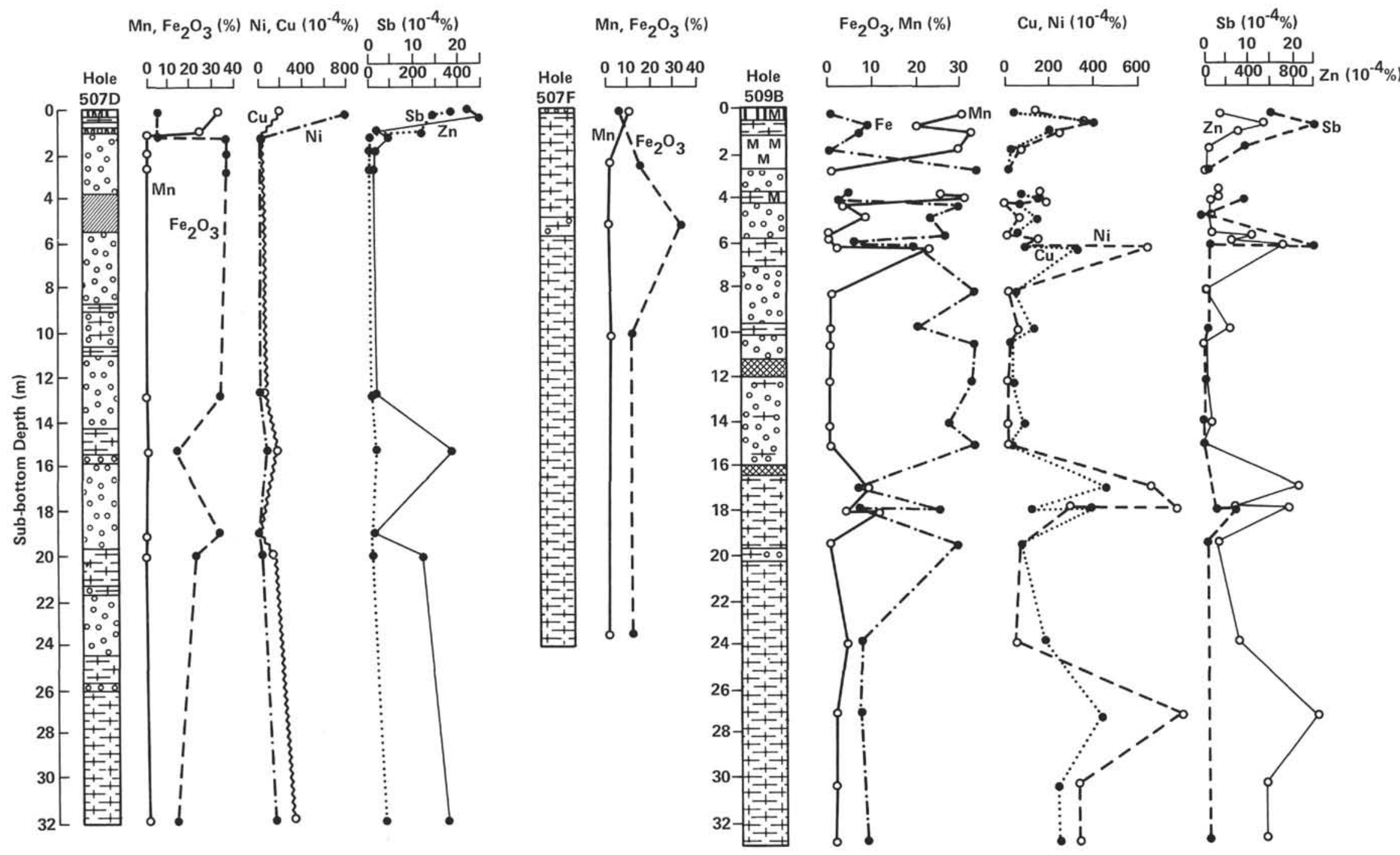




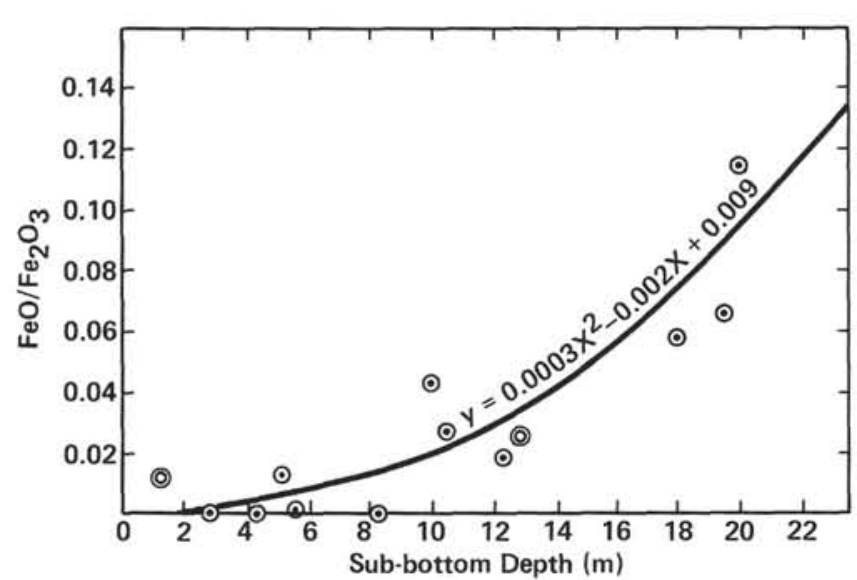

Figure 2. $\mathrm{FeO} / \mathrm{Fe}_{2} \mathrm{O}_{3}$ ratio in smectites plotted against sub-bottom depth in mounds sections. (Circles with dots $=$ Hole 509B; double circles $=$ Hole 507D.)

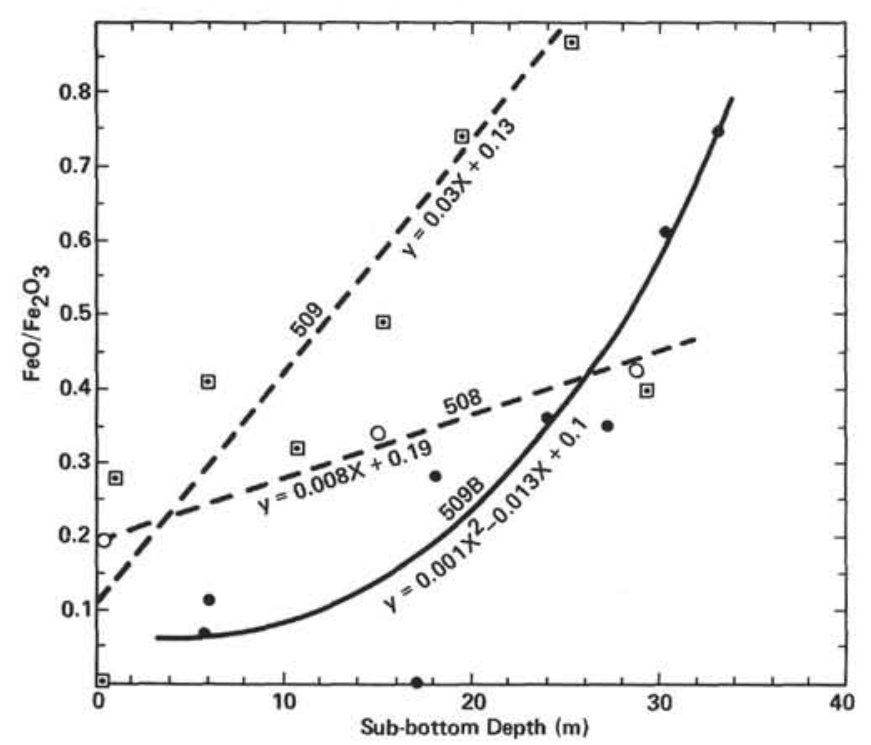

Figure 3. $\mathrm{FeO} / \mathrm{Fe}_{2} \mathrm{O}_{3}$ ratio in pelagic oozes in Holes 509B, 509, and 508 plotted against sub-bottom depth. (Open squares $=$ Hole 509; open circles $=$ Hole 508; solid circles $=$ Hole 509B.) (Data for the deepest samples from Hole 508, in and near the lithified layer, were removed.)

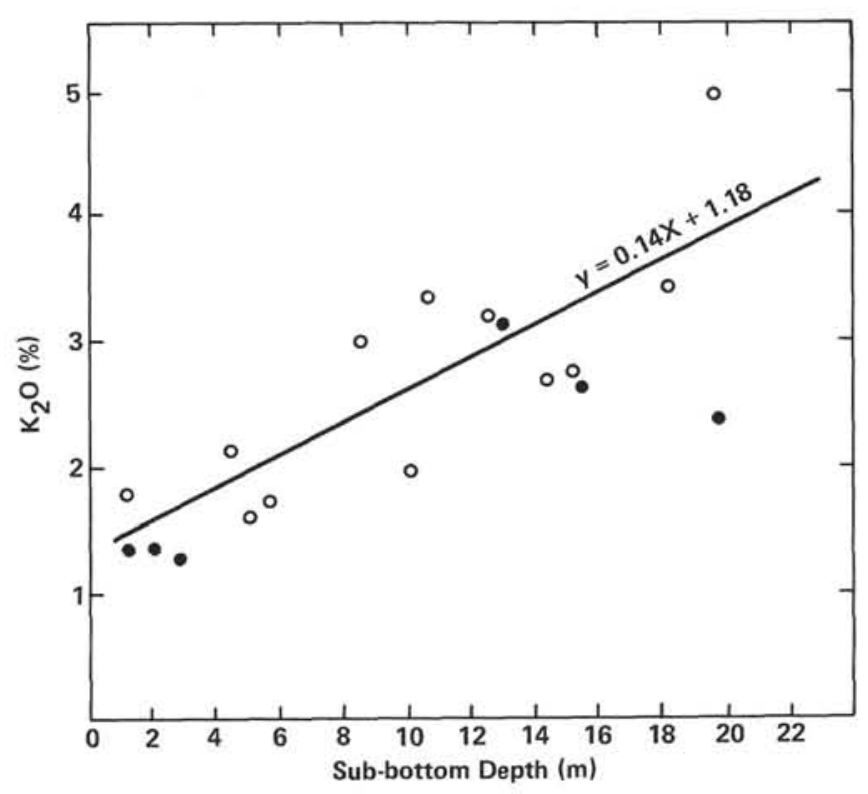

Figure 4. $\mathrm{K}_{2} \mathrm{O}$ concentration in smectites plotted against sub-bottom depth in mounds sections. (Open circles $=$ Hole 509B; solid circles $=$ Hole 507D.) 


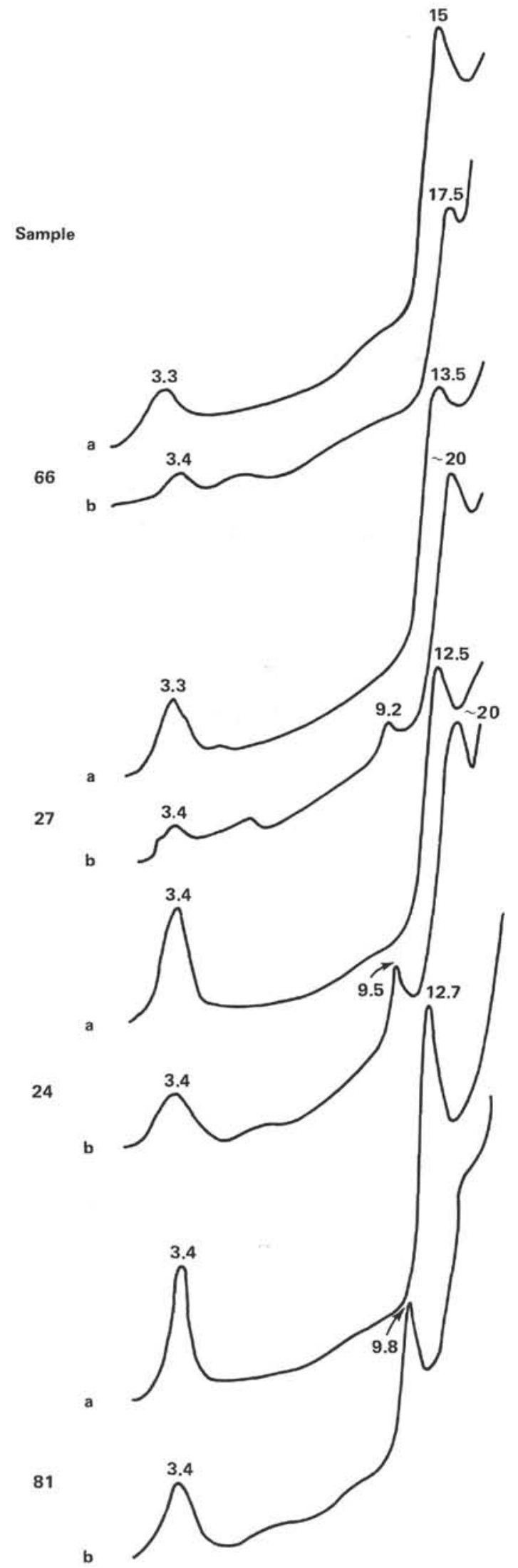

Figure 5. X-ray diffractograms of $<0.001-\mathrm{mm}$ fractions of hydrothermal green clays from Holes 507D and 509B. (Sample numbers in Tables 1, 3 and text; $\mathrm{a}=$ air-dried samples; $\mathrm{b}=$ ethylene-glycol saturated samples.)

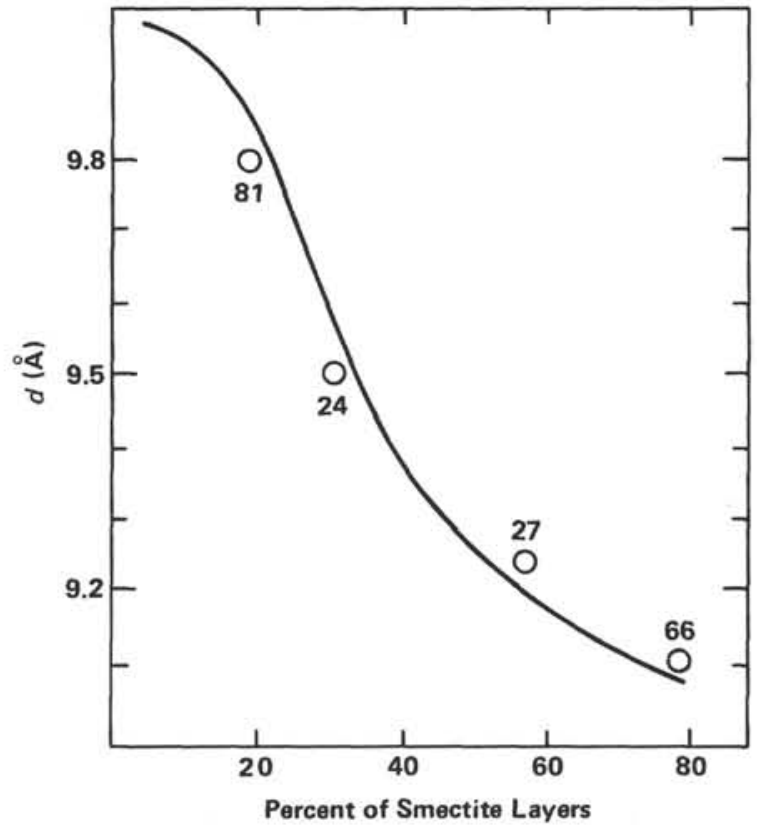

Figure 6. Content of smectite layers in analyzed mixed-layered micasmectite minerals. (Relationships between the $d(\AA)$ of basal mica (001) and secondary smectite (002) reflections and the content of smectite layers are given by Gradusov, 1971.) 


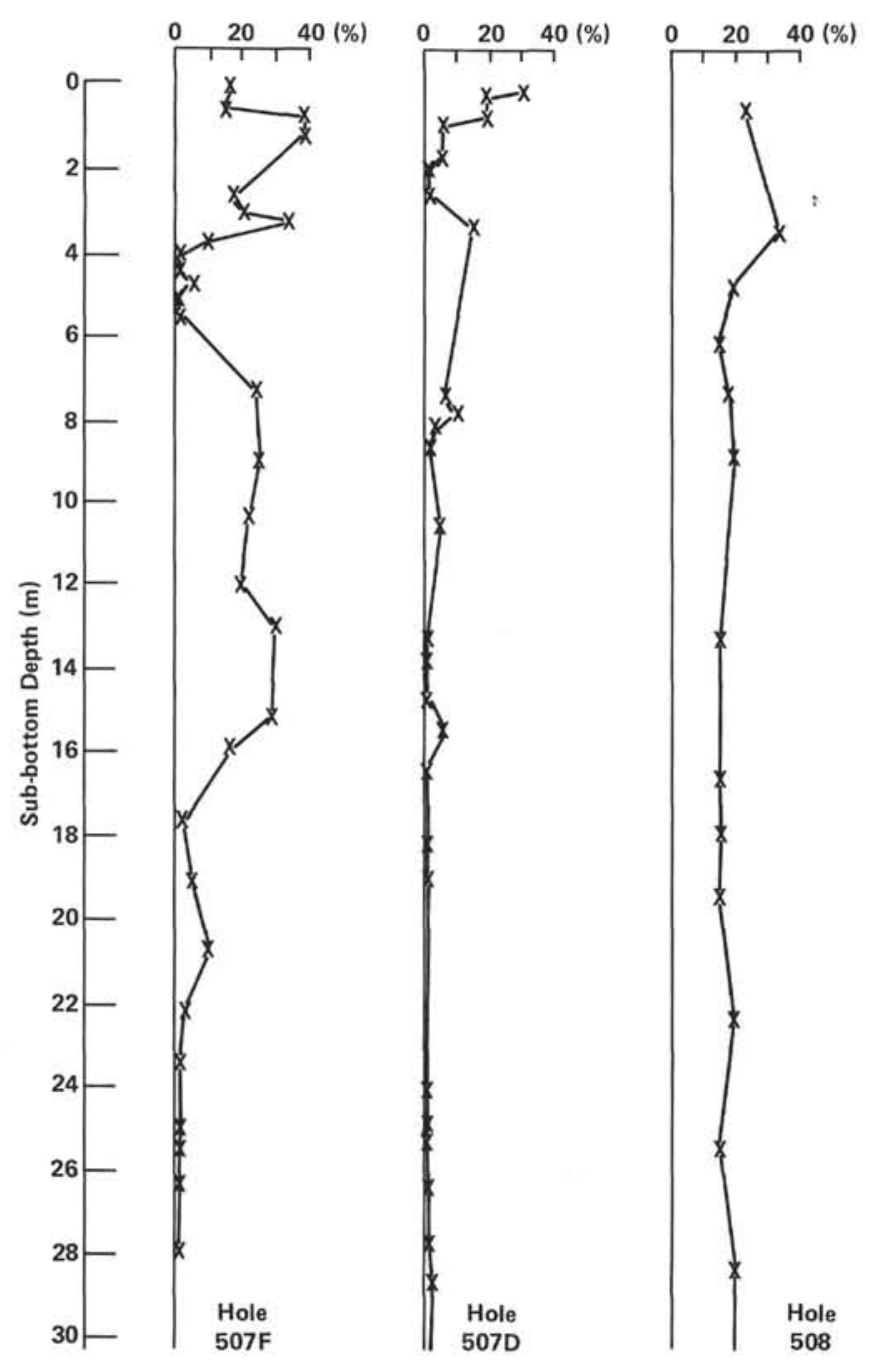

Figure 7. Variation in content of siliceous microfossils in Holes 507D, $507 \mathrm{~F}$, and 508 on the basis of smear-slide data. (See site summaries, this volume.)

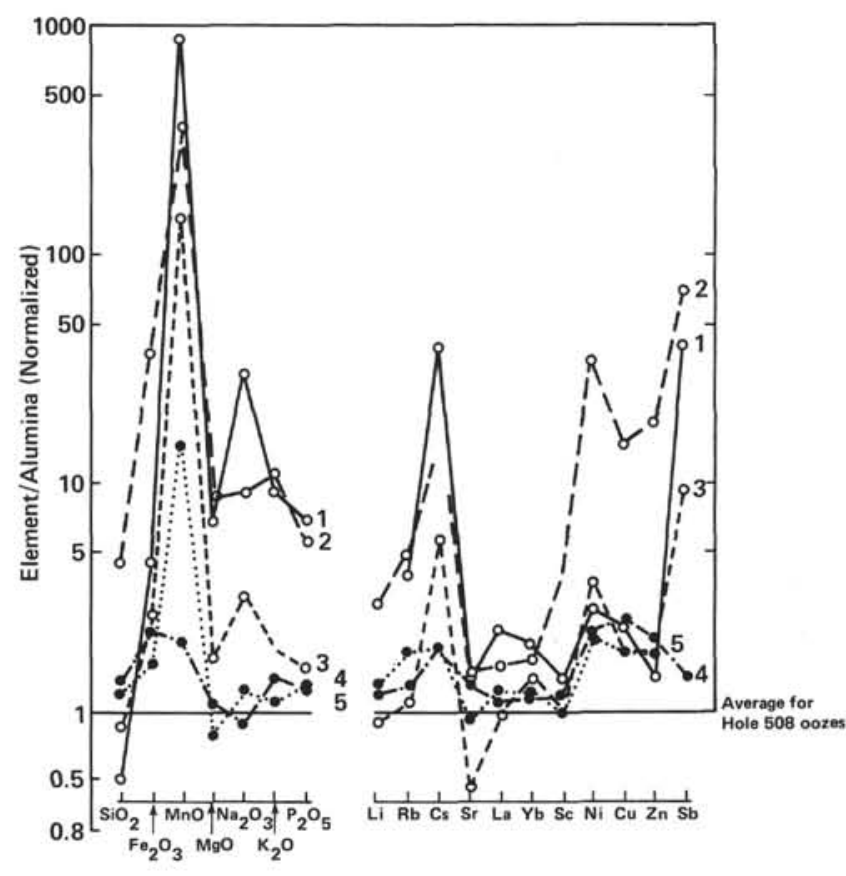

Figure 8. Element-to-alumina ratios in Mn crusts of mounds and in uppermost oxidized layers of pelagic oozes, normalized to ratios in average low heat-flow area sediments, Hole 508. $(1=$ lower $\mathrm{Mn}$ crusts; $2=\mathrm{Fe}-\mathrm{Mn}$ oxide sediment; $3=$ upper Mn crusts; $4=$ uppermost oxidized layers of high heat-flow area pelagic oozes (offmounds sediments); $5=$ uppermost oxidized layers of low heatflow area pelagic oozes.)

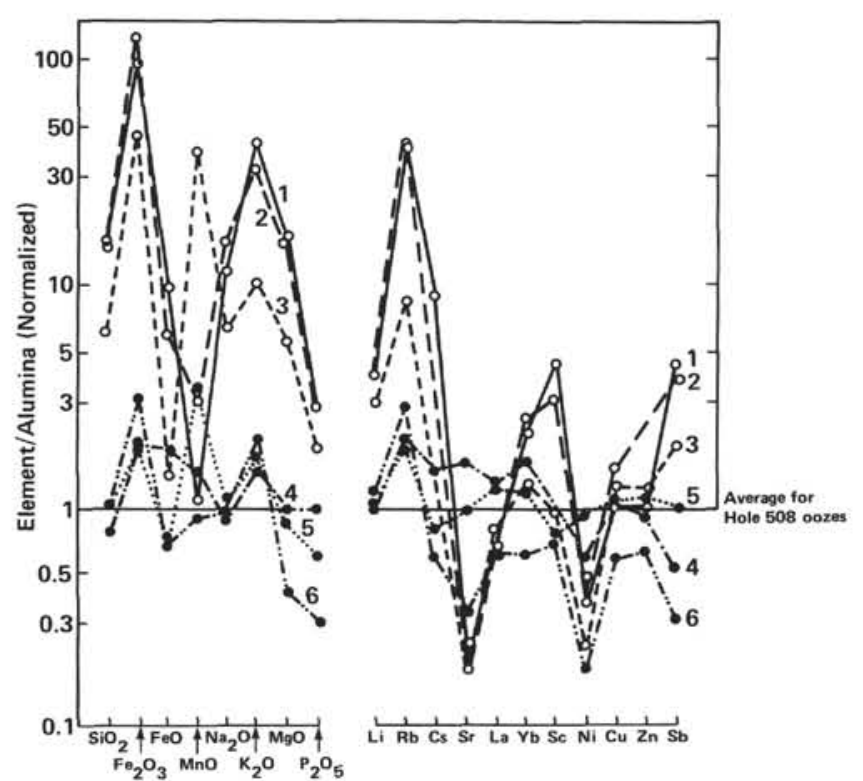

Figure 9. Element-to-alumina ratios in mounds smectites and pelagic oozes, normalized to ratios in average low heat-flow sediments, Hole 508. $(1=$ lower smectites; $2=$ middle smectites; $3=$ upper smectites (some contamination by Mn crusts may take place); 4 = lower pelagic sediments in mound sections; 5 = pelagic oozes alternating with smectite in mounds sections; $6=\mathrm{Al}$-rich smectite.) 
Table 10. Average absolute masses of elements in mounds, off-mounds, and low heat-flow area sediments.

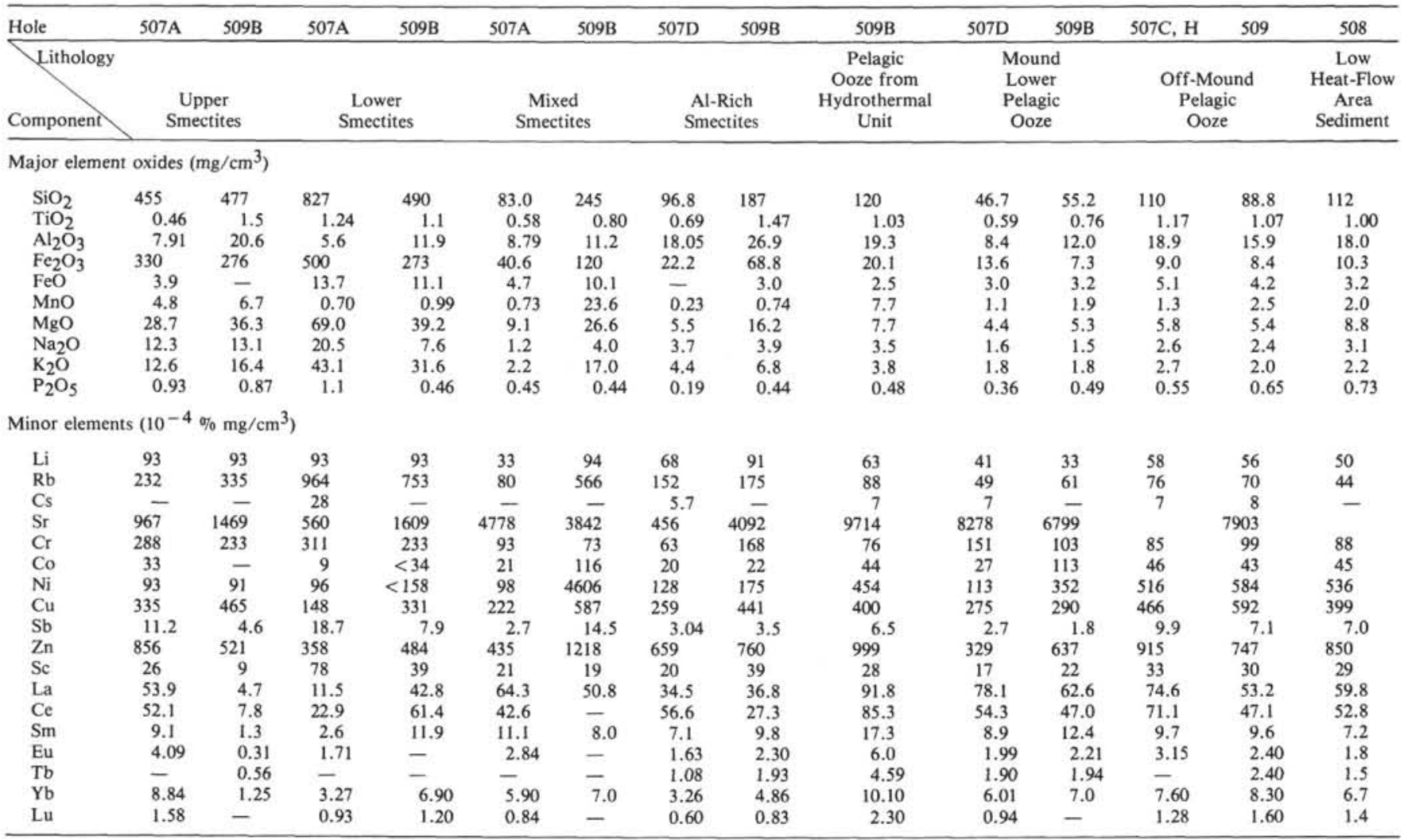

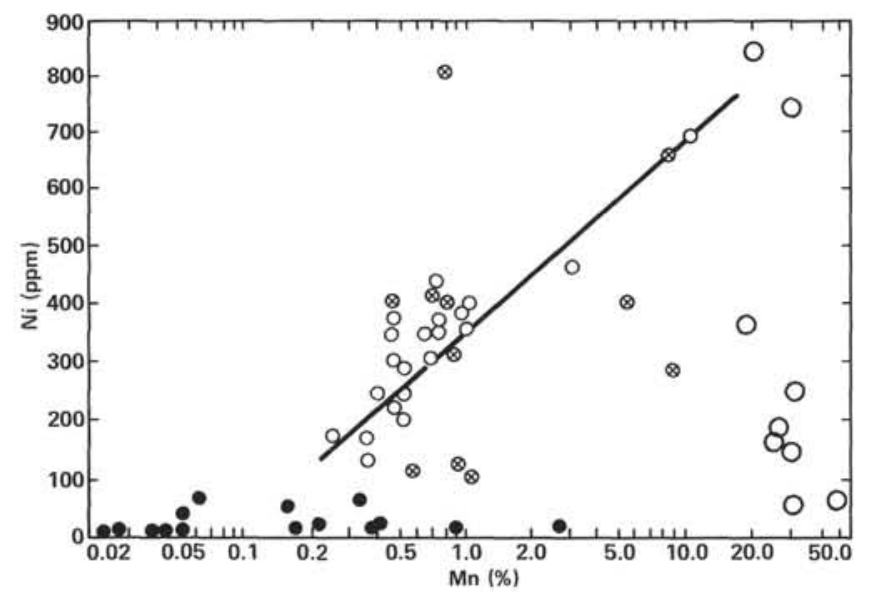

Figure 10. Ni vs. Mn correlation in hydrothermal and pelagic sediments of mounds areas. (Open circles $=$ off-mounds and crossed circles $=$ mounds pelagic sediments; large open circles $=$ Mn crusts and $\mathrm{Fe}-\mathrm{Mn}$ oxide sediment; solid circles $=$ Fe-rich smectites.)

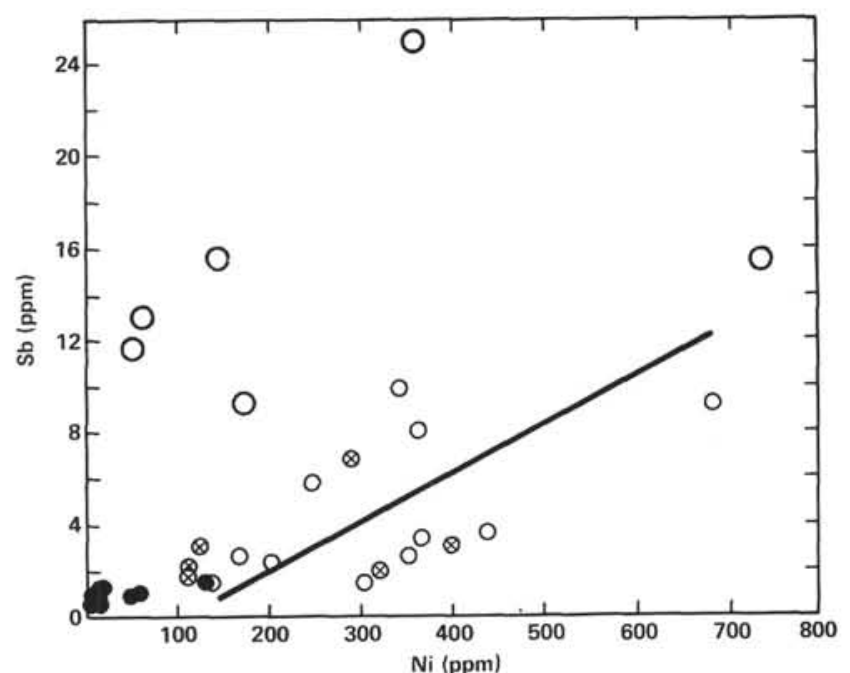

Figure 11. Sb vs. Ni correlation in hydrothermal and pelagic sediments (symbols as in Fig. 11). 


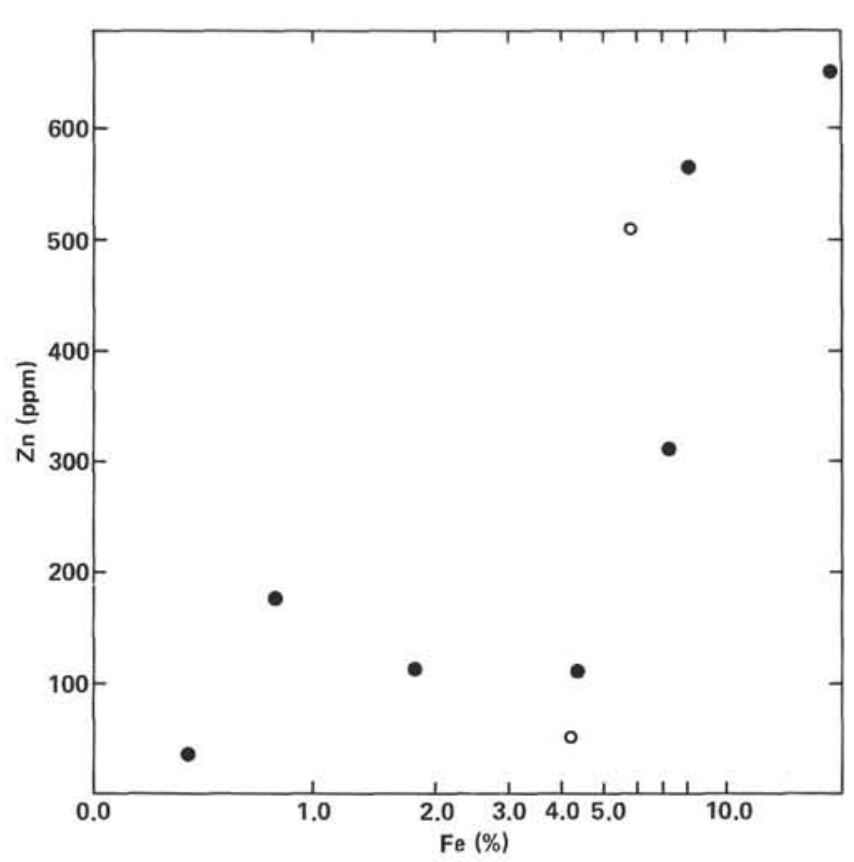

Figure $12 . \mathrm{Zn}$ vs. Fe correlation in manganese crusts and in Fe-Mn oxide sediment. (Open circles $=$ Hole 507D; solid circles $=$ Hole 509B.)

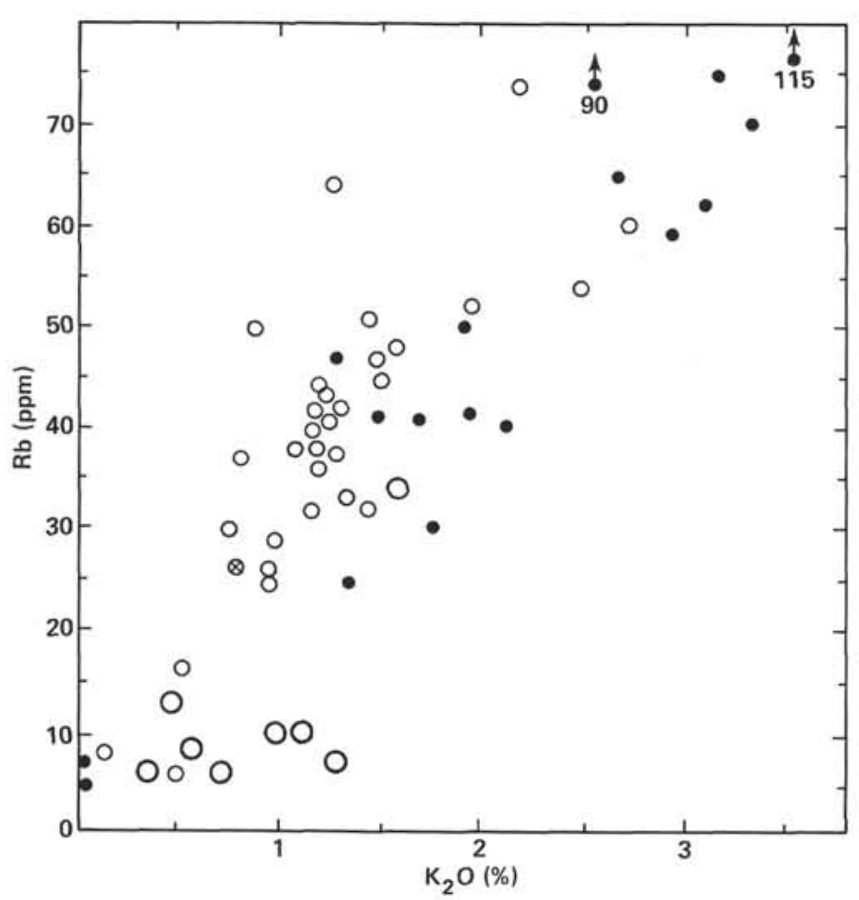

Figure 13 . $\mathrm{Rb}$ vs. $\mathrm{K}_{2} \mathrm{O}$ content in hydrothermal and pelagic sediments (symbols as in Fig. 11).

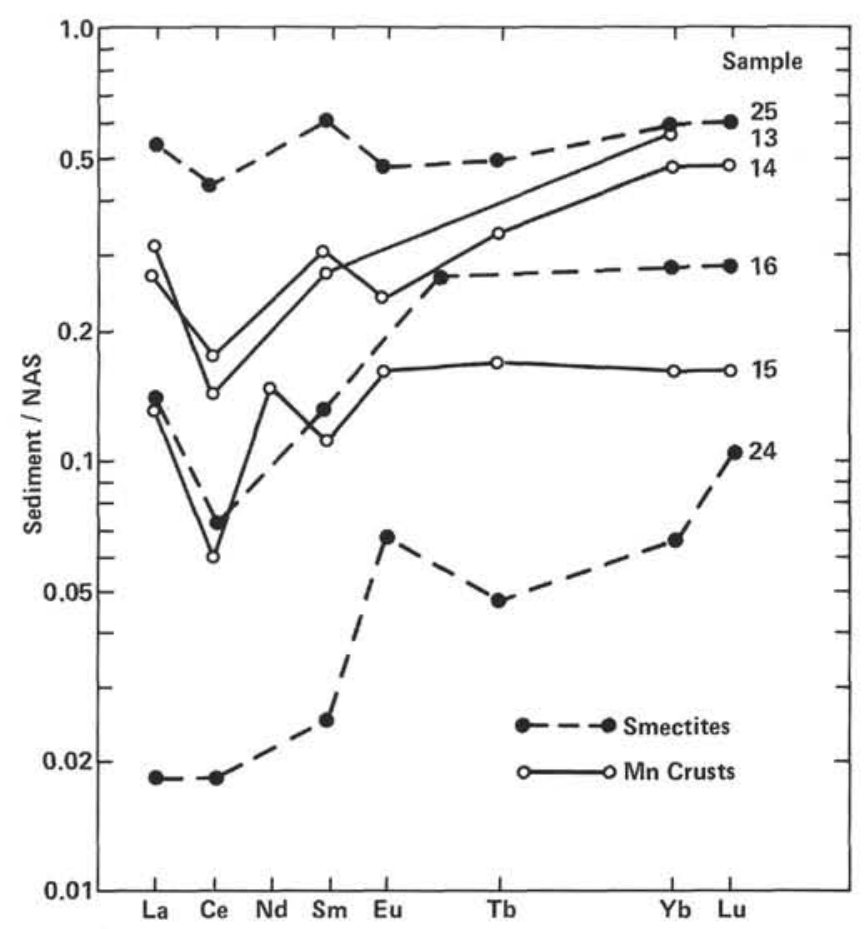

Figure 14. Distribution of rare earth elements in hydrothermal sediments, Hole 507D, normalized on North American shale (NAS) distribution.

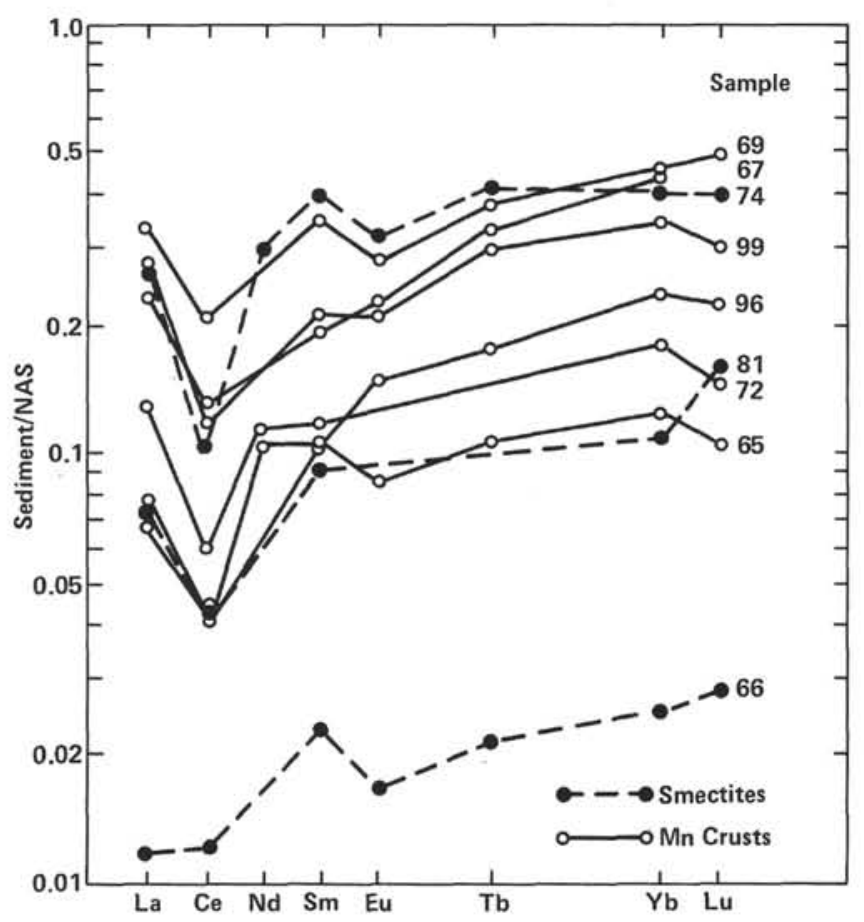

Figure 15. Distribution of rare earth elements in hydrothermal sediments, Hole 509B, normalized on North American shale (NAS) distribution. 


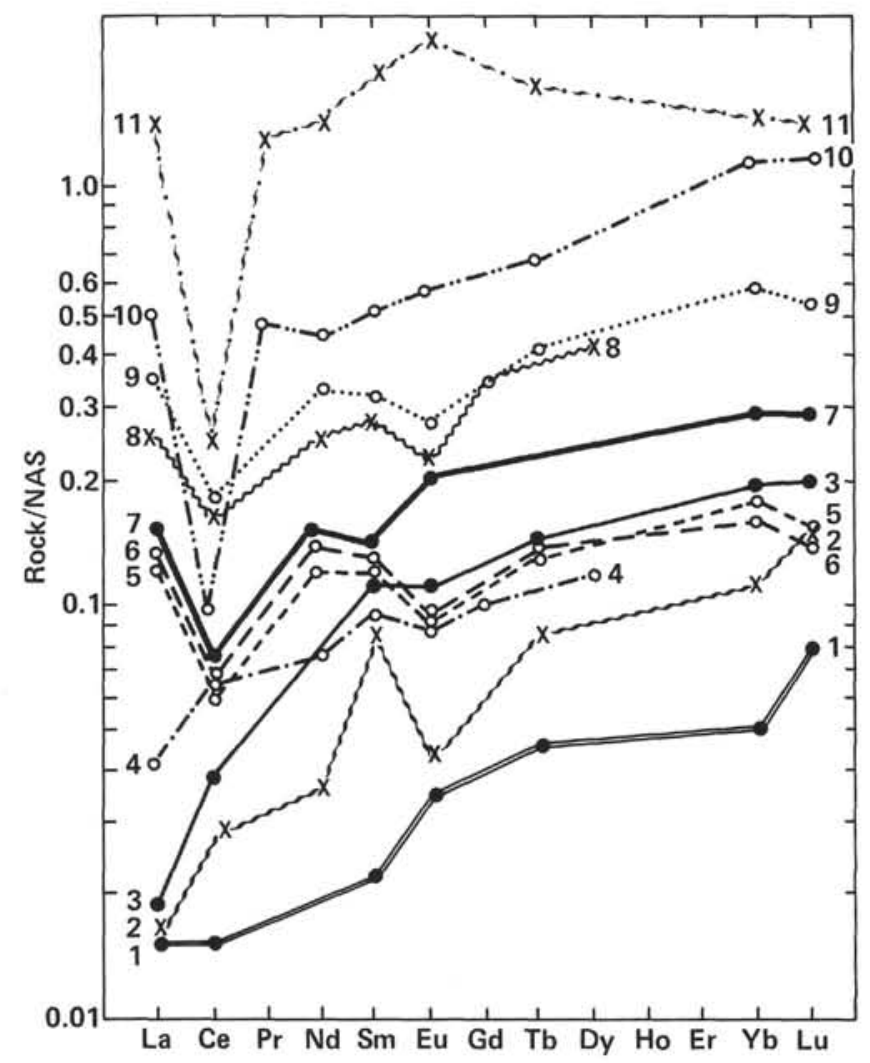

Figure 16. NAS-normalized distribution of rare earth elements in hydrothermally derived products from ocean spreading zone and continental ophiolite sediments. $(1=$ smectites with low rare-earth element concentrations from Galapagos hydrothermal mounds (average of three samples); 2 = Fe-rich hydrothermally derived product from northeast Pacific [Piper et al., 1975]; 3 = vein smectites from Hole 504B basalts, Costa Rica Rift (Sharaskin et al., in press); 4 = Mn-enriched sediments, Malinelo deposit, Italy [Bonatti, Zerbi, et al., 1976]; $5=\mathrm{Fe}-\mathrm{Mn}$ oxide sediment from Galapagos mounds; $6=$ lower Mn crusts of Galapagos mounds; $7=$ Fe-rich smectites of Galapagos mounds; 8 = oxidized hydrothermal pyrite concretions from Romanch deep (Bonatti, Honnorez-Guerstein, et al., 1976); $9=$ upper manganese crusts of Galapagos mounds; $10=$ metalliferous sediments from the East Pacific Rise [Piper and Graef, 1974]; 11 = metalliferous sediments of Troodos massif, Cyprus [Robertson and Fleet, 1976].)

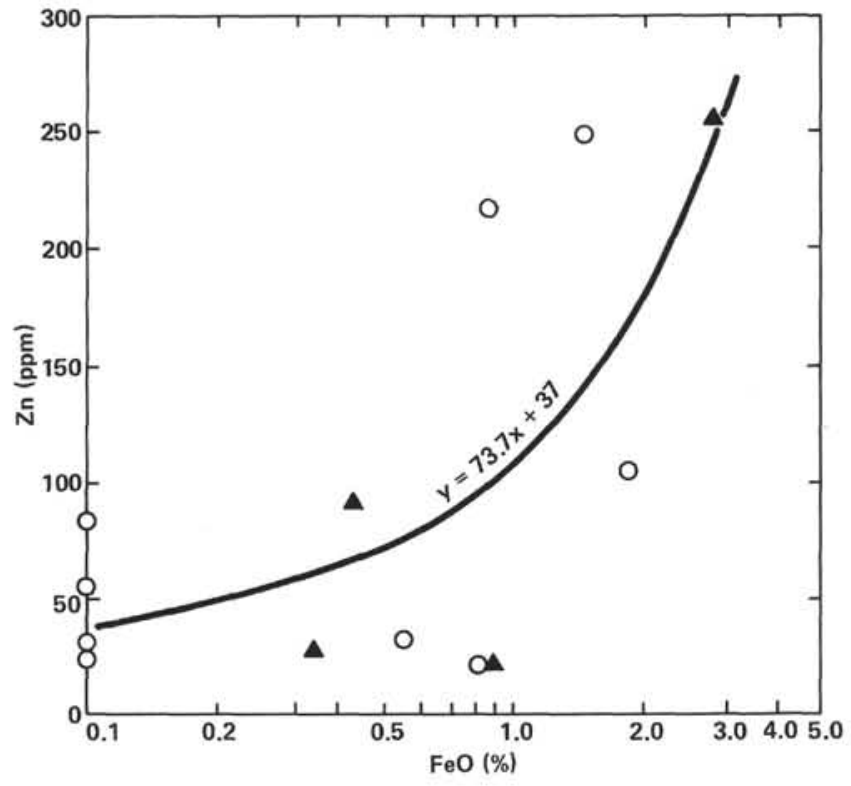

Figure 17. $\mathrm{Zn}$ vs. FeO content in mounds smectites carbonate-free basis. (Open circles $=$ Hole 509B; triangles $=$ Hole 507D.) 